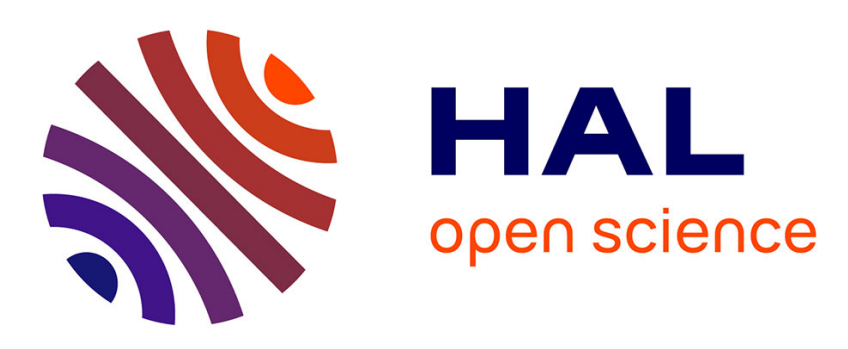

\title{
Mantle and Recycled Oceanic Crustal Components in Mantle Xenoliths From Northeastern China and their Mantle Sources
}

Peng Guo, Dmitri Ionov, Wen-liang Xu, Chun-guang Wang, Jin-peng Luan

\section{- To cite this version:}

Peng Guo, Dmitri Ionov, Wen-liang Xu, Chun-guang Wang, Jin-peng Luan. Mantle and Recycled Oceanic Crustal Components in Mantle Xenoliths From Northeastern China and their Mantle Sources. Journal of Geophysical Research: Solid Earth, 2020, 125 (4), 10.1029/2019JB018232 . hal-02733039

\section{HAL Id: hal-02733039 \\ https://hal.umontpellier.fr/hal-02733039}

Submitted on 2 Jun 2020

HAL is a multi-disciplinary open access archive for the deposit and dissemination of scientific research documents, whether they are published or not. The documents may come from teaching and research institutions in France or abroad, or from public or private research centers.
L'archive ouverte pluridisciplinaire HAL, est destinée au dépôt et à la diffusion de documents scientifiques de niveau recherche, publiés ou non, émanant des établissements d'enseignement et de recherche français ou étrangers, des laboratoires publics ou privés. 


\section{JGR Solid Earth}

\section{RESEARCH ARTICLE 10.1029/2019JB018232 \\ Key Points: \\ - Pyroxenites from northeastern \\ Mantle and Recycled Oceanic Crustal Components in Mantle Xenoliths From Northeastern China and their Mantle Sources} China formed by reactions of peridotites with recycled oceanic crust-derived silicate melts

- Infiltration of carbonated asthenosphere-derived carbonatite melts into the lithospheric mantle produced wehrlite

- Upwelling of asthenosphere was the major factor in the evolution of the lithospheric mantle beneath northeastern China

Supporting Information:

- Supporting Information S1

Correspondence to:

W.-L. Xu,

xuwl@jlu.edu.cn

Citation:

Guo, P., Ionov, D. A., Xu, W.-L., Wang, C.-G., \& Luan, J.-P. (2020). Mantle and recycled oceanic crustal components in mantle xenoliths from northeastern China and their mantle sources. Journal of Geophysical Research: Solid Earth, 125, e2019JB018232. https://doi. org/10.1029/2019JB018232

Received 18 JUN 2019

Accepted 29 MAR 2020

Accepted article online 6 APR 2020

(C)2020. American Geophysical Union. All Rights Reserved.

\author{
Peng Guo ${ }^{1,2,3}$, Dmitri A. Ionov ${ }^{3,4} \mathbb{D}$, Wen-Liang Xu' ${ }^{1}$, Chun-Guang Wang ${ }^{1}$ (D), \\ and Jin-Peng Luan ${ }^{1}$ \\ ${ }^{1}$ College of Earth Sciences, Jilin University, Changchun, China, ${ }^{2}$ Department of Earth and Space Sciences, Southern \\ University of Science and Technology, Shenzhen, China, ${ }^{3}$ Géosciences Montpellier, Université de Montpellier, \\ Montpellier, France, ${ }^{4}$ Guangzhou Institute of Geochemistry, Chinese Academy of Sciences, Guangzhou, China
}

\section{Introduction}

The formation and evolution of the continental lithospheric mantle (CLM) are critical to understand the development of Earth's continents. Eastern China contains the Archean North China Craton (NCC) and surrounding orogenic belts and is an excellent setting to examine how the CLM formed and evolved. Recent geophysical and geochemical studies suggest that older cold and thick lithospheric mantle in the eastern NCC was destroyed and replaced by newer hot and juvenile CLM during the late Mesozoic (Chu et al., 2009; Gao et al., 2002; Menzies et al., 1993; Wu et al., 2006; Xu, 2001; Zheng et al., 2006). The westward subduction of the Paleo-Pacific slab is now accepted as the principal trigger for the NCC attenuation (Xu, 2014; Zhu et al., 2012), although southward subduction of the Paleo-Asian oceanic slab (Chen et al., 2016) and northward subduction of the Yangtze plate (Gao et al., 2002) could have played a role as well. The orogenic belts in northeastern (NE) China have been significantly affected by the westward subduction of the (Paleo-)Pacific slab as well (Xu, Liu, et al., 2013). Yet, compared to the NCC, the formation and evolution of the CLM beneath post-Archean domains of NE China are less well constrained.

Cenozoic basaltic rocks hosting mantle xenoliths are widespread in NE China (e.g., Shuangliao, Yitong, Jiaohe, and Wangqing) and adjacent far eastern Russia (Figure 1). These mantle xenoliths are mainly lherzolites with rare harzburgites, wehrlites, and pyroxenites (Guo et al., 2017; Ionov et al., 1995; Wu et al., 2003; Xu et al., 1996, 1998; Yu et al., 2009, 2010; Zhang et al., 2011, 2019; Zhou et al., 2007). 

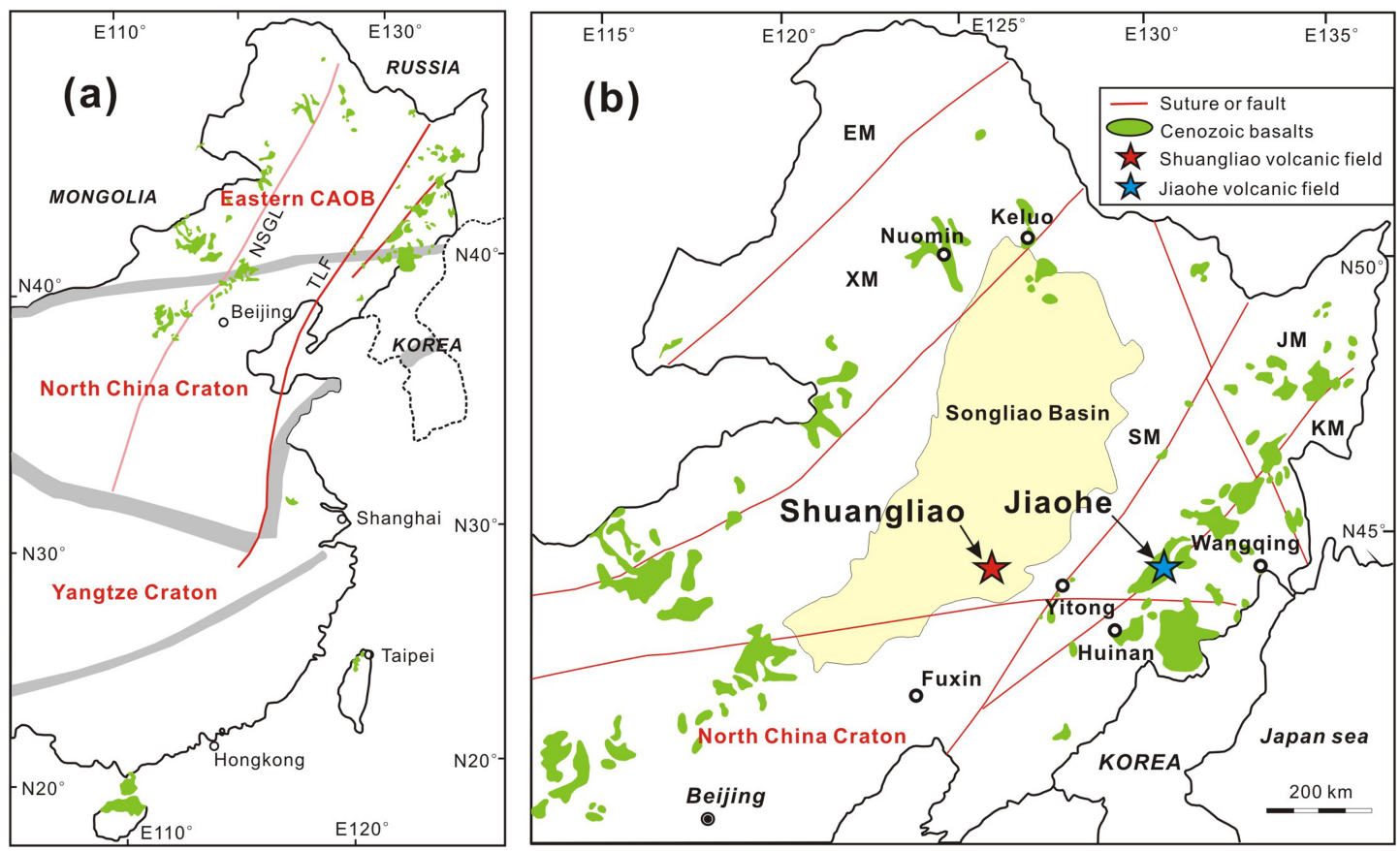

Figure 1. (a) A sketch map showing the tectonic framework and the distribution of Cenozoic basalts in eastern China. CAOB: Central Asian Orogenic Belt; NSGL: North-South Gravity Lineament; TLF: Tan-Lu Fault. (b) Sample locations, major tectonic units, and Cenozoic basalts in northeastern China. EB: Erguna Block; JB: Jiamusi Block; KB: Khanka Block; SB: Songnen Block; XM: Xing'an Block.

Whole rock major and trace element compositions and Re-Os isotopic data for the peridotites suggest that the CLM beneath these regions is composed mainly of juvenile mantle with minor ancient components, with Re-depletion ages ranging from Proterozoic to recent for individual xenoliths (Wu et al., 2003; Zhou et al., 2007). Guo et al. (2017) argued that the CLM experienced melt extraction in the Paleoproterozoic and the ancient CLM was replaced by juvenile mantle material accreted from asthenosphere in the Phanerozoic.

Some peridotites from NE China show Nd-Hf isotopic decoupling (Yu et al., 2009) or contain interstitial K-rich glass (Xu et al., 1996), likely reflecting pervasive mantle metasomatism. Some earlier publications argued for the role of asthenosphere-derived fluids/melts in the formation of metasomatized peridotites from NE China (Xu et al., 1998, 2003). Yu et al. (2010) reported garnet pyroxenite xenoliths from Jiaohe that exhibit trace element and Sr-Nd-O isotopic features resembling those of altered lower oceanic crust and suggested that the garnet pyroxenites are remnants of recycled oceanic crust in the CLM. Melted components of the recycled crustal materials may have migrated upward and metasomatized the CLM. However, no conclusive evidence has been found that recycled materials played a role in the formation of metasomatized peridotites. Thus, the composition and origin of metasomatic agents and their effects on the evolution of the CLM beneath NE China continue to be debated.

Peridotite xenoliths are direct samples of the lithospheric mantle and record a variety of processes, including partial melting and mantle metasomatism (e.g., Pearson et al., 2014). Their mineral compositions may trace metasomatism in the CLM (Foley, 2008). Pyroxenite is the second most common rock type among basalt-hosted mantle xenoliths after spinel peridotite. The studies of pyroxenites may be complementary to those of metasomatized peridotites, because pyroxenites form in zones of high melt/rock ratios in the mantle (Garrido \& Bodinier, 1999).

In this study, we report detailed data on petrography, mineral and rock chemistry, O-isotope composition of olivine, and in situ $\mathrm{Sr}$ isotope composition of clinopyroxene for a suite of peridotite and pyroxenite xenoliths carried by the Cenozoic Jiaohe and Shuangliao basalts in NE China. These data provide new insights into the evolution of the CLM beneath post-Archean domains of NE China. 


\section{Geological Background and Samples}

\subsection{Geological Background}

The study area in NE China (Figure 1) is located in the eastern segment of the Central Asian Orogenic Belt (CAOB), sandwiched between the Siberian and North China cratons (Sengör et al., 1993). The most important events in the Phanerozoic history of the area were the subduction in the Paleo-Asian oceanic plate, followed by its closure and amalgamation of several microcontinents (from west to east: the Erguna, Xing'an, Songnen, Jiamusi, and Khanka blocks; Figure 1b) mostly in the Paleozoic (Liu et al., 2017; Xiao et al., 2015). Since the Mesozoic, NE China has been affected by the subduction of the (Paleo-)Pacific plate in the east (Xu, Pei, et al., 2013) and of the Mongol-Okhotsk plate in the northwest (Tang et al., 2016). Recent seismic tomography identified a stagnant oceanic slab in the mantle transition zone beneath eastern China (Huang \& Zhao, 2006; Wei et al., 2015), which was attributed to the subduction of the Pacific plate.

The Songnen Block (SB in Figure 1b) comprises the Songliao basin filled with thick Mesozoic strata and the Lesser Xing'an and Zhangguangcai ranges. Precambrian crustal basement with zircon ${ }^{207} \mathrm{~Pb} /{ }^{206} \mathrm{~Pb}$ ages of 1808-1873 Ma (Pei et al., 2007; Wang et al., 2006) was discovered in southern Songliao basin. The Lesser Xing'an and Zhangguangcai ranges consist of voluminous Phanerozoic granites with minor Neoproterozoic granitoids (Luan et al., 2017; Wang, Xu, et al., 2017; Wu et al., 2011). The granites have a broad range of zircon $\mathrm{Hf}$ isotopic values $\left(\varepsilon_{\mathrm{Hf}}=-8.6\right.$ to +13.7$)$ and model ages $\left(\mathrm{T}_{\mathrm{DM} 2}=454-1998 \mathrm{Ma}\right)$, suggesting crustal growth from Paleoproterozoic to mid-Phanerozoic (Guo et al., 2018; Wang, Xu, et al., 2017).

Cenozoic alkali basalts are common in NE China. Their origins are linked to continental extension and upper mantle convection induced by the subduction of the Pacific plate (Guo et al., 2016; Tang et al., 2014). The Jiaohe volcanic field (site 17JH) is located in the central Jilin Province, $200 \mathrm{~km}$ east of the Songliao basin, near the Dun-Mi fault (Figure 1(b)). The lavas are basanites and alkaline olivine basalts with 2-24 Ma K-Ar ages (Wang, 1996). Abundant, fresh mantle xenoliths (spinel lherzolites, harzburgites, wehrlites, and pyroxenites) 3-15 cm in diameter are found in a quarry at Yiqisong (Yu et al., 2009, 2010; Zhou et al., 2007). Rhenium-Os isotopic compositions of 10 peridotites from this locality reported by Zhou et al. (2007) show ${ }^{187} \mathrm{Os} /{ }^{188}$ Os ratios of $0.1178-0.1396$, with Re depletion ages $\left(\mathrm{T}_{\mathrm{RD}}\right)$ of 1.1 and $1.6 \mathrm{Ga}$ for the two most refractory harzburgites $\left(\mathrm{Al}_{2} \mathrm{O}_{3}<2 \%\right)$. Oxygen isotopic compositions reported for a few olivine-free garnet pyroxenites from the same site (Yu et al., 2010) show lack of O isotopic equilibrium between garnet, spinel, and clinopyroxene.

The Shuangliao volcanic field in the southeastern Songliao basin (Figure 1b) includes eight eruption centers; mantle xenoliths were found at three of them, that is, Bolishan (Site 17SL1), Aobaoshan (17SL2), and Bobotushan (17SL3). The volcanic rocks from these three sites are basanites with Ar-Ar ages of 48-51 Ma (Xu et al., 2012). The mantle xenoliths are spinel lherzolites, harzburgites, and pyroxenites. Rhenium-Os isotopic compositions have been reported for 11 Shuangliao spinel peridotites (Wu et al., 2003). Five refractory samples $\left(\mathrm{Al}_{2} \mathrm{O}_{3}<2 \%\right)$ have ${ }^{187} \mathrm{Os} /{ }^{188}$ Os ratios of $0.1181-0.1263$ and $\mathrm{T}_{\mathrm{RD}}$ of $0.5-1.6 \mathrm{Ga}$.

\subsection{Sample Preparation and Description}

Fifteen xenoliths from Jiaohe and 18 xenoliths from Shuangliao were selected from a larger collection to represent major mantle xenolith types at these locations. The xenoliths are $3-10 \mathrm{~cm}$ in size and were cut from host lava to obtain material for thin sections and mineral separation. Ten of the largest xenoliths were crushed and powdered for whole-rock (WR) analyses. Essential petrologic and chemical data for the xenoliths are listed in Table 1 including modal compositions (from point-counting in thin sections), Mg\# of olivine $\left[\mathrm{Mg} \#_{\mathrm{Ol}}=\mathrm{Mg} /(\mathrm{Mg}+\mathrm{Fe})_{\mathrm{at}}\right], \mathrm{Cr} \#$ of spinel $\left[\mathrm{Cr} \#_{\mathrm{Sp}}=\mathrm{Cr} /(\mathrm{Cr}+\mathrm{Al})_{\mathrm{at}}\right]$, and equilibrium temperatures $(\mathrm{T})$. 2.2.1. Pyroxenite Xenoliths

The pyroxenites are classified in three groups. The group 1 pyroxenites include three garnet-spinel pyroxenites made up of clinopyroxene (cpx), orthopyroxene (opx), garnet (grt), and spinel (sp), as well as a spinel pyroxenite that shows textural and chemical similarities to the garnet-bearing samples. Garnet commonly forms as rims around spinel (Figure 2a). Olivine has low modal abundances $(\leq 6 \%)$. It is subhedral and occurs around garnet, likely due to association with garnet formation.

The Groups 2 and 3 pyroxenites include seven garnet-free rocks consisting of cpx and opx, with rare spinel $(\leq 0.5 \%)$. The pyroxenes have curvilinear grain boundaries, spinel commonly occurs as inclusions in pyroxenes. The clinopyroxenes in these two groups (green Cr-diopside) contain less Al than those in Group 1. Rare 
Table 1

Summary of Essential Petrologic and Geochemical Data on Samples From NE China

\begin{tabular}{|c|c|c|c|c|c|c|c|c|c|c|}
\hline \multirow[b]{2}{*}{ Sample } & \multirow[b]{2}{*}{ Rock type } & \multirow{2}{*}{$\frac{\mathrm{TBKN}\left({ }^{\circ} \mathrm{C}\right)}{\mathrm{cpx}-\mathrm{opx}}$} & \multirow{2}{*}{$\frac{\mathrm{Ol}}{\mathrm{Mg \#}}$} & \multirow{2}{*}{$\frac{\mathrm{Sp}}{\mathrm{Cr} \#}$} & \multicolumn{6}{|c|}{ modal compositions (\%) } \\
\hline & & & & & $\mathrm{Ol}$ & Cpx & Opx & $\mathrm{Sp}$ & Grt & Fs \\
\hline \multicolumn{11}{|c|}{ Metasomatized Peridotites } \\
\hline 17JH14 & Wehrlite & & 0.92 & 0.57 & 68.7 & 23.5 & & 7.3 & & $\operatorname{Tr}$ \\
\hline 17JH16 & Lherzolite & 953 & 0.91 & 0.24 & 70.1 & 5.7 & 23.8 & 0.4 & & \\
\hline 17JH24 & Lherzolite & 968 & 0.91 & 0.25 & 68.8 & 5.6 & 24.1 & 1.5 & & \\
\hline 17SL1-7 & Harzburgite & 986 & 0.91 & 0.35 & 68.9 & 2.2 & 28.0 & 0.9 & & \\
\hline 17SL1-8 & Harzburgite & 1021 & 0.91 & 0.45 & 66.1 & 2.5 & 30.6 & 0.8 & & \\
\hline 17SL1-23 & Lherzolite & 964 & 0.91 & 0.19 & 44.7 & 8.4 & 43.4 & 3.5 & & \\
\hline 17SL1-24 & Lherzolite & 1029 & 0.90 & 0.18 & 62.0 & 13 & 20.0 & 4.0 & & \\
\hline 17SL1-25 & Lherzolite & 849 & 0.90 & 0.34 & 56.0 & 15 & 26.0 & 3.0 & & \\
\hline 17SL3-15 & Lherzolite & 1006 & 0.92 & 0.26 & 77.3 & 6.9 & 15.1 & 0.7 & & \\
\hline 17SL3-16 & Harzburgite & 1114 & 0.92 & 0.52 & 69.7 & 1.1 & 29.0 & 0.2 & & \\
\hline \multicolumn{11}{|c|}{ Unmetasomatized Peridotites } \\
\hline 17JH4 & Lherzolite & 998 & 0.89 & 0.09 & 50.7 & 12.3 & 36.1 & 0.9 & & \\
\hline 17JH18 & Lherzolite & 860 & 0.90 & 0.14 & 62.3 & 10.1 & 25.4 & 2.2 & & \\
\hline 17JH21 & Lherzolite & 985 & 0.90 & 0.17 & 62.6 & 12.9 & 22.6 & 1.9 & & \\
\hline 17SL1-1 & Lherzolite & 963 & 0.90 & 0.15 & 57.2 & 7.3 & 34.3 & 1.2 & & \\
\hline 17SL1-2 & Lherzolite & 1049 & 0.90 & 0.11 & 63.9 & 8.1 & 25.4 & 2.6 & & \\
\hline 17SL1-16 & Lherzolite & 844 & 0.90 & 0.10 & 59.7 & 11.3 & 26.8 & 2.2 & & \\
\hline 17SL1-18 & Lherzolite & 904 & 0.90 & 0.12 & 53.9 & 12.4 & 31.1 & 2.6 & & \\
\hline 17SL2-3 & Lherzolite & 893 & 0.90 & 0.11 & 58.2 & 10.2 & 29.7 & 1.9 & & \\
\hline 17SL2-6 & Lherzolite & 890 & 0.90 & 0.08 & 44.4 & 17.3 & 32.7 & 5.6 & & \\
\hline 17SL2-7 & Lherzolite & 871 & 0.90 & 0.09 & 62.6 & 9.7 & 24.8 & 2.9 & & \\
\hline \multicolumn{11}{|c|}{ Group 1 pyroxenites } \\
\hline 17JH6 & Grt websterite & 1062 & 0.88 & 0.04 & 2.3 & 59.6 & 21.8 & 9.8 & 6.5 & $\operatorname{Tr}$ \\
\hline 17JH11 & Grt clinopyroxenite & 1048 & 0.88 & 0.02 & 3.1 & 74.1 & 5.6 & 4.7 & 12.5 & $\operatorname{Tr}$ \\
\hline 17JH12 & Grt clinopyroxenite & 951 & & 0.01 & & 73.5 & 4.6 & 16.8 & 5.1 & \\
\hline 17JH7 & Websterite & 1020 & 0.89 & 0.03 & 6.2 & 50.1 & 38.0 & 5.7 & & $\operatorname{Tr}$ \\
\hline \multicolumn{11}{|c|}{ Group 2 pyroxenites } \\
\hline 17JH2 & Websterite & 898 & & 0.11 & & 72.4 & 28.4 & 0.2 & & $\operatorname{Tr}$ \\
\hline 17JH3 & Websterite & 1035 & & 0.12 & & 79.4 & 20.3 & 0.3 & & $\operatorname{Tr}$ \\
\hline 17JH8 & Websterite & 1041 & & 0.30 & & 68.3 & 31.3 & 0.4 & & \\
\hline 17SL1-21 & Websterite & 958 & 0.89 & 0.09 & $\operatorname{Tr}$ & 79.2 & 14.7 & 0.4 & & \\
\hline 17SL3-7 & Websterite & 807 & 0.90 & 0.12 & $\operatorname{Tr}$ & 75.9 & 23.5 & 0.5 & & \\
\hline \multicolumn{11}{|c|}{ Group 3 pyroxenites } \\
\hline 17JH1 & Websterite & 1018 & 0.86 & 0.14 & $\operatorname{Tr}$ & 84.3 & 15.3 & 0.1 & & $\operatorname{Tr}$ \\
\hline 17SL1-22 & Websterite & 948 & 0.90 & 0.08 & $\operatorname{Tr}$ & 65.6 & 32.1 & 2.2 & & \\
\hline
\end{tabular}

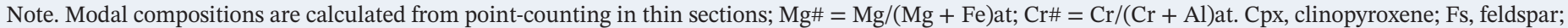
Grt, garnet; Ol, olivine; Opx, orthopyroxene; Sp, spinel; Tr, trace. Sample names with 17JH and 17SL are from Jiaohe and Shuangliao, respectively.

fine-grained olivine $(<0.1 \%)$ occurs as relic grains in cpx-opx reaction zones (Figure $2 b)$. Two of these pyroxenites (17JH1 and 17SL1-22) are classified into separate Group 3 due to their specific petrography and isotopic characteristics. 17SL1-22 contains opx surrounded by fine-grained olivine and cpx (Figure 2c) and has more spinel than the other pyroxenites $(2.2 \%$ vs. $\leq 0.5 \%)$.

A prominent petrographic feature of all groups of pyroxenites is the presence of accessory feldspars, usually as thin irregular aggregates along grain boundaries, cross-cutting veins, or inclusions in pyroxene grains (Figure 2d).

\subsubsection{Peridotite Xenoliths}

The peridotites comprise unmetasomatized lherzolites (7-17\% cpx) and metasomatized rocks. The former exhibits protogranular, fine- to coarse-grained texture. The latter includes a wehrlite (17JH14), three harzburgites, and six lherzolites. The metasomatized peridotites contain no volatile-bearing minerals. The wehrlite has porphyroclastic texture and contains no opx and much spinel ( 7\%) (Figure 2e). The harzburgites and five lherzolites display protogranular texture, with irregular pyroxene grain boundaries and serrated reaction rims. They contain $1-15 \% \mathrm{cpx}$ and $\leq 4 \%$ spinel. Sample $17 \mathrm{SL} 1-23$ is a metasomatized lherzolite 

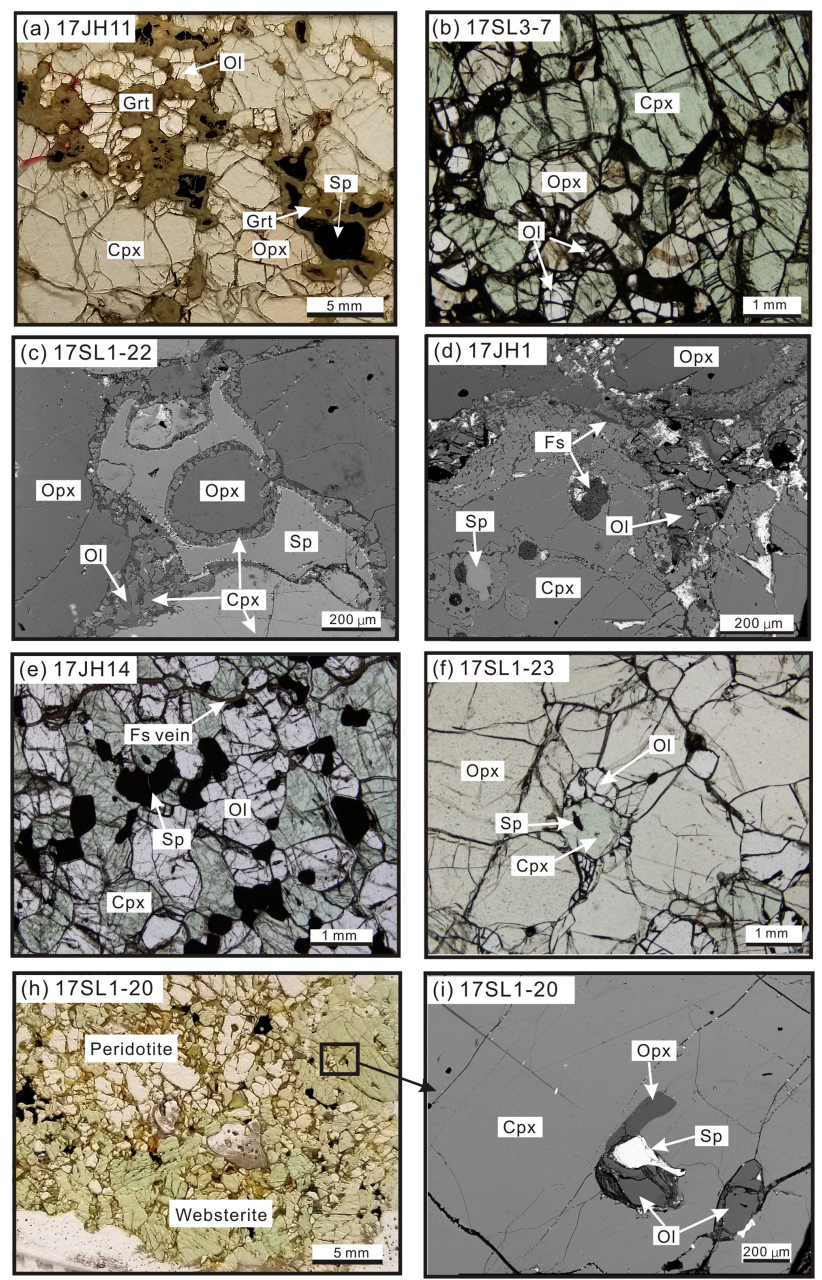

Figure 2. Photomicrographs of mantle xenoliths from Jiaohe and Shuangliao (sample numbers are in upper left corners). Abbreviations: $\mathrm{Cpx}=$ clinopyroxene; $\mathrm{Fs}=$ feldspar; Grt = garnet; $\mathrm{Ol}=$ olivine; Opx = orthopyroxene; $\mathrm{Sp}=$ spinel. (a) Group 1 pyroxenite, with garnet mantling spinel and olivine associated with garnet. (b) Group 2 pyroxenite, with fine-grained olivine among pyroxene grains. (c) Group 3 pyroxenite, with Opx surrounded by fine-grained olivine and Cpx. (d) Group 3 pyroxenite, feldspars occur as thin irregular aggregates along grain boundaries, and inclusions in Cpx; fine-grained olivine occurs as relic grains in reaction zones. (e) Wehrlite containing no Opx, but much spinel. (f) An Opx-rich (43\%) lherzolite with porphyroclastic microstructure. (h) Composite xenolith with gradational transition from peridotite to websterite. (i) Large Cpx grain in a websterite with a fine-grained pocket of $\mathrm{Ol}$, Opx and Sp. with porphyroclastic texture (Figure 2f); it contains less olivine (45\%) and more opx (43\%) than other metasomatized peridotites.

\subsubsection{Composite Xenoliths}

Two composite xenoliths 17JH5 and 17SL1-20 show lithological transitions from peridotite to websterite in thin sections, with smaller cpx and larger olivine grains in the peridotite (Figure $2 \mathrm{~h}$ ). A fine-grained pocket of olivine, opx, and spinel occurs within a large $(\sim 5 \mathrm{~mm})$ cpx grain in websterite 17SL1-20 (Figure 2i).

\section{Results}

A detailed description of all analytical methods used in this study is provided in the supporting information.

\subsection{Whole Rock Major and Trace Element Compositions}

The whole-rock major element compositions of eight Jiaohe xenoliths and two Shuangliao lherzolites are given in Table S1. These samples have very low loss on ignition (LOI, -0.16 to $0.72 \mathrm{wt} . \%$ ), consistent with negligible alteration from petrographic observations. All three group 1 pyroxenites have high $\mathrm{Al}_{2} \mathrm{O}_{3}$ (10.9-16.8 wt.\%) and $\mathrm{CaO}$ (8.9-13.5 wt.\%) contents, and moderate Mg\# (0.86-0.88). Only one Group 2 pyroxenite was analyzed; it has lower $\mathrm{Al}_{2} \mathrm{O}_{3}$ content (5.4 wt.\%), higher $\mathrm{CaO}$ content (15.1 wt.\%), and higher $\mathrm{Mg \#}$ of 0.89 . The lherzolites are moderately refractory with 1.2-2.9 wt.\% $\mathrm{Al}_{2} \mathrm{O}_{3}, 1.5-2.8$ wt.\% $\mathrm{CaO}$, and $\mathrm{Mg} \#$ of $0.90-0.91$. Six peridotites in this study are located on plot of $\mathrm{Al}_{2} \mathrm{O}_{3}$ versus $\mathrm{FeO}$ between the 5-1 and 2-0 GPa decompression partial melting lines (Figure 3). By contrast, many literature peridotites from the same localities plot above the melt-extraction domain and must have been enriched in iron.

Trace element abundances in eight Jiaohe xenoliths are given in Table S1. Group 1 pyroxenite 17JH6 is HREE-enriched, whereas other Group 1 pyroxenites exhibit nearly flat REE patterns and minor positive Eu anomalies (Figures $4 \mathrm{a}$ and $4 \mathrm{~b}$ ). The REE pattern of Group 2 pyroxenite 17JH8 is similar to that of Group 1 pyroxenite 17JH12. Both groups of pyroxenites have positive $\mathrm{U}$ and $\mathrm{Sr}$ anomalies and negative Ti anomalies. Two lherzolites containing 10-13\% cpx have LREE-depleted REE patterns, whereas two low-cpx (6\%) lherzolites have HREE-depleted and LREE-enriched REE patterns (Figures 4c and 4d).

\subsection{Mineral Major and Trace Element Compositions}

Major and trace element compositions of minerals are given in Tables S2 and S3 and illustrated in Figures 5-7.

Altogether, pyroxenes from Groups 2 and 3 pyroxenites and from peridotite xenoliths (including literature data) define negative correlations of $\mathrm{Al}_{2} \mathrm{O}_{3}$ with $\mathrm{Cr}_{2} \mathrm{O}_{3}$ and $\mathrm{Mg}$ \#, and a positive correlation with $\mathrm{Na}_{2} \mathrm{O}$ (Figure 5). Clinopyroxenes in Group 1 pyroxenites differ from those in the majority of garnet-free xenoliths by higher $\mathrm{Al}_{2} \mathrm{O}_{3}\left(>6\right.$ wt.\%) and lower $\mathrm{Cr}_{2} \mathrm{O}_{3}$ ( $\leq 0.3$ wt.\%) (Figures 5a- 5c) and have convex-upward REE patterns with maxima near Eu (Figure 6a), reflecting HREE partitioning to coexisting garnet. The garnets have low $\mathrm{Cr}_{2} \mathrm{O}_{3}(0.06-0.30$ wt.\%) and broadranges of $\mathrm{CaO}\left(4.05-6.68\right.$ wt.\%) and $\mathrm{HREE}\left(\mathrm{Yb}_{\mathrm{N}}=11-115\right)$. Spinel in Group 1 pyroxenites has very low $\mathrm{Cr} \#$ of 0.01-0.04. Spinel in many peridotites has high $\mathrm{TiO}_{2}$ reaching 0.6 wt.\% (Figure 7). Olivine in pyroxenites has lower $\mathrm{Mg} \#$ than olivine in peridotites ( $\leq 0.89$ vs. $\geq 0.90)$. Feldspar in pyroxenites is K-rich (3.9-8.6 wt.\% $\left.\mathrm{K}_{2} \mathrm{O}\right)$. 


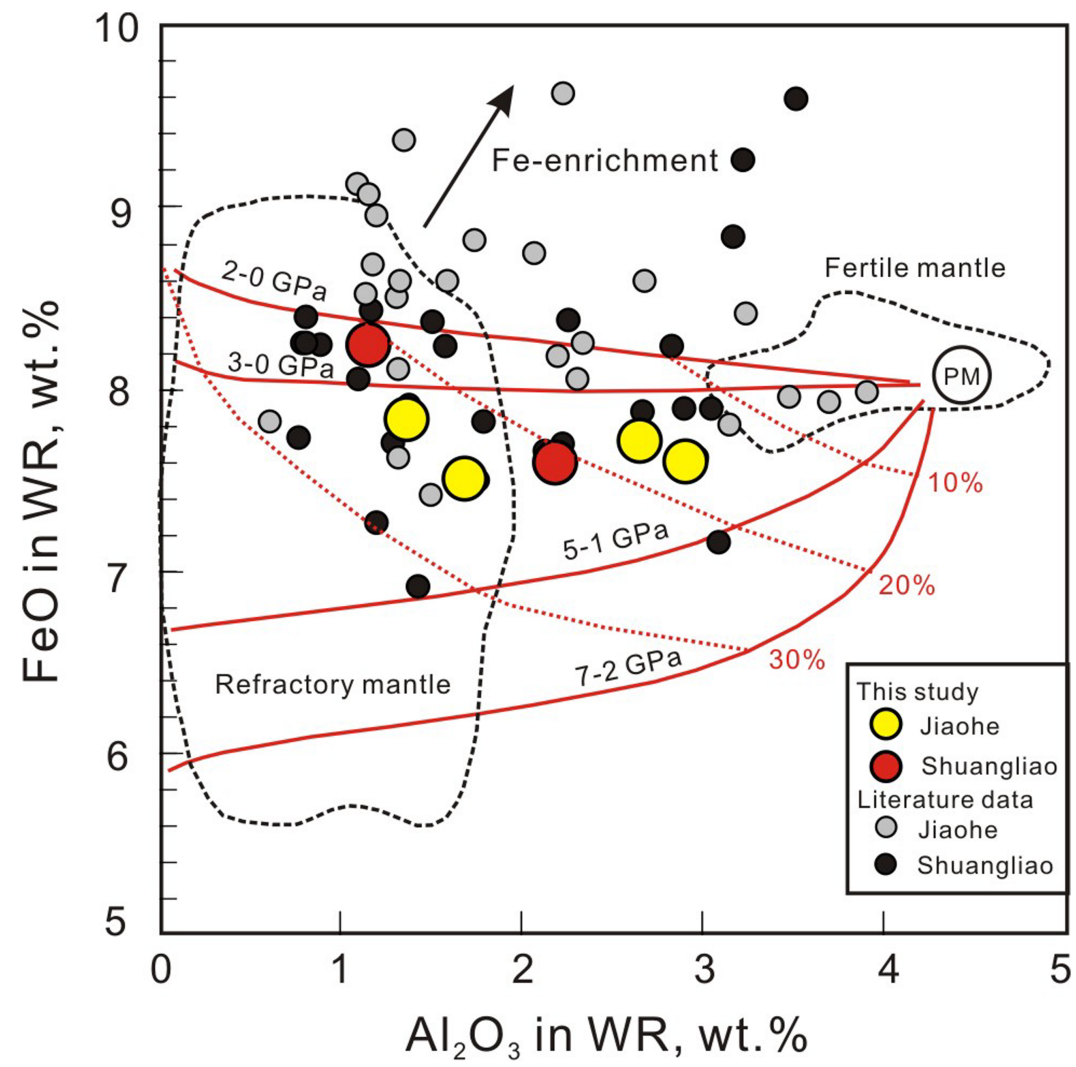

Figure 3. A plot of $\mathrm{Al}_{2} \mathrm{O}_{3}$ versus $\mathrm{FeO}$ for whole-rock (WR) peridotite xenoliths from Jiaohe and Shuangliao including literature data from Wu et al. (2003), Yu et al. (2009), and Zhou et al. (2007). Also shown are primitive mantle (PM) after McDonough and Sun (1995), a field of refractory mantle from Doucet et al. (2012), and a field for fertile off-craton peridotite xenoliths from Vitim and Tariat in Central Asia (Ionov et al., 2005; Ionov, 2007). Continuous red lines are residues of polybaric melting formed at 2-0, 3-0, 5-1 and 7-2 GPa (Herzberg, 2004). Literature data plotting above the melting path at the lowest pressure contain too much Fe to be pure melting residues of fertile mantle and experienced postmelting Fe-enrichments, most likely by reaction with evolved mafic melts.

Clinopyroxene grains in Group 3 pyroxenite $17 \mathrm{JH} 1$ are chemically zoned with higher $\mathrm{Na}_{2} \mathrm{O}(2.2 \mathrm{wt} . \%), \mathrm{Sr}$ (207 ppm), and LREE $\left((\mathrm{La} / \mathrm{Yb})_{N}=9.3\right)$ and lower $\mathrm{Mg} \#(0.88)$ in rims than in cores $\left(1.4\right.$ wt.\% $\mathrm{Na}_{2} \mathrm{O}$, $67 \mathrm{ppm} \mathrm{Sr},(\mathrm{La} / \mathrm{Yb})_{N}=1.6$, and $\left.\mathrm{Mg} \#=0.89\right)$.

Clinopyroxenes in peridotites and pyroxenites have a broad range of REE patterns from LREE-depleted to convex-upward and LREE-enriched (Figure 6), and common negative anomalies of $\mathrm{Zr}, \mathrm{Hf}, \mathrm{Nb}$, and $\mathrm{Ta}$, and positive anomalies of Th, U, and Sr. Clinopyroxene grains in wehrlite 17JH14 are zoned, with higher $\mathrm{Sr}(270 \mathrm{ppm})$ and $\operatorname{LREE}\left((\mathrm{La} / \mathrm{Yb})_{N}=11.4\right)$ in rims than in cores $\left(\mathrm{Sr}=67 \mathrm{ppm} ;(\mathrm{La} / \mathrm{Yb})_{N}=5.4\right)$.

\subsection{Sr Isotope Composition of Clinopyroxene}

The in situ ${ }^{87} \mathrm{Sr} /{ }^{86} \mathrm{Sr}$ ratios for cpx obtained by LA-ICPMS are given in Table S4 and shown in Figure 8a. The ${ }^{87} \mathrm{Sr} /{ }^{86} \mathrm{Sr}$ ratios of clinopyroxenes from Group 1 pyroxenites range from 0.7022 to 0.7035 and are lower than whole rock ${ }^{87} \mathrm{Sr} /{ }^{86} \mathrm{Sr}$ ratios of the pyroxenites $(0.7036-0.7042)$ reported by Yu et al. (2010). The clinopyroxenes from Group 2 pyroxenites have ${ }^{87} \mathrm{Sr} /{ }^{86} \mathrm{Sr}$ ratios of $0.7020-0.7025$. The clinopyroxenes from Group 3 pyroxenite $17 \mathrm{SL1}-22$ have ${ }^{87} \mathrm{Sr} /{ }^{86} \mathrm{Sr}$ ratios of $0.7033-0.7038$, whereas the rim of zoned clinopyroxene from Sample 17JH1 has a higher ${ }^{87} \mathrm{Sr} /{ }^{86} \mathrm{Sr}$ ratio (0.7034) than its core (0.7019; Figure 9a).

The ${ }^{87} \mathrm{Sr} /{ }^{86} \mathrm{Sr}$ ratios for cpx in peridotite xenoliths range from 0.7022 to 0.7055 , with lower values in LREE-depleted lherzolites than in LREE-enriched samples. Among them, the cpx in two cpx-poor Jiaohe lherzolites (17JH16 and 17JH24) has the highest ${ }^{87} \mathrm{Sr} /{ }^{86} \mathrm{Sr}$ ratios $(0.7052-0.7055)$. The rim of zoned cpx from wehrlite $17 \mathrm{JH} 14$ has a higher ${ }^{87} \mathrm{Sr} /{ }^{86} \mathrm{Sr}$ ratio (0.7034) than its core (0.7026; Figure 9c). 

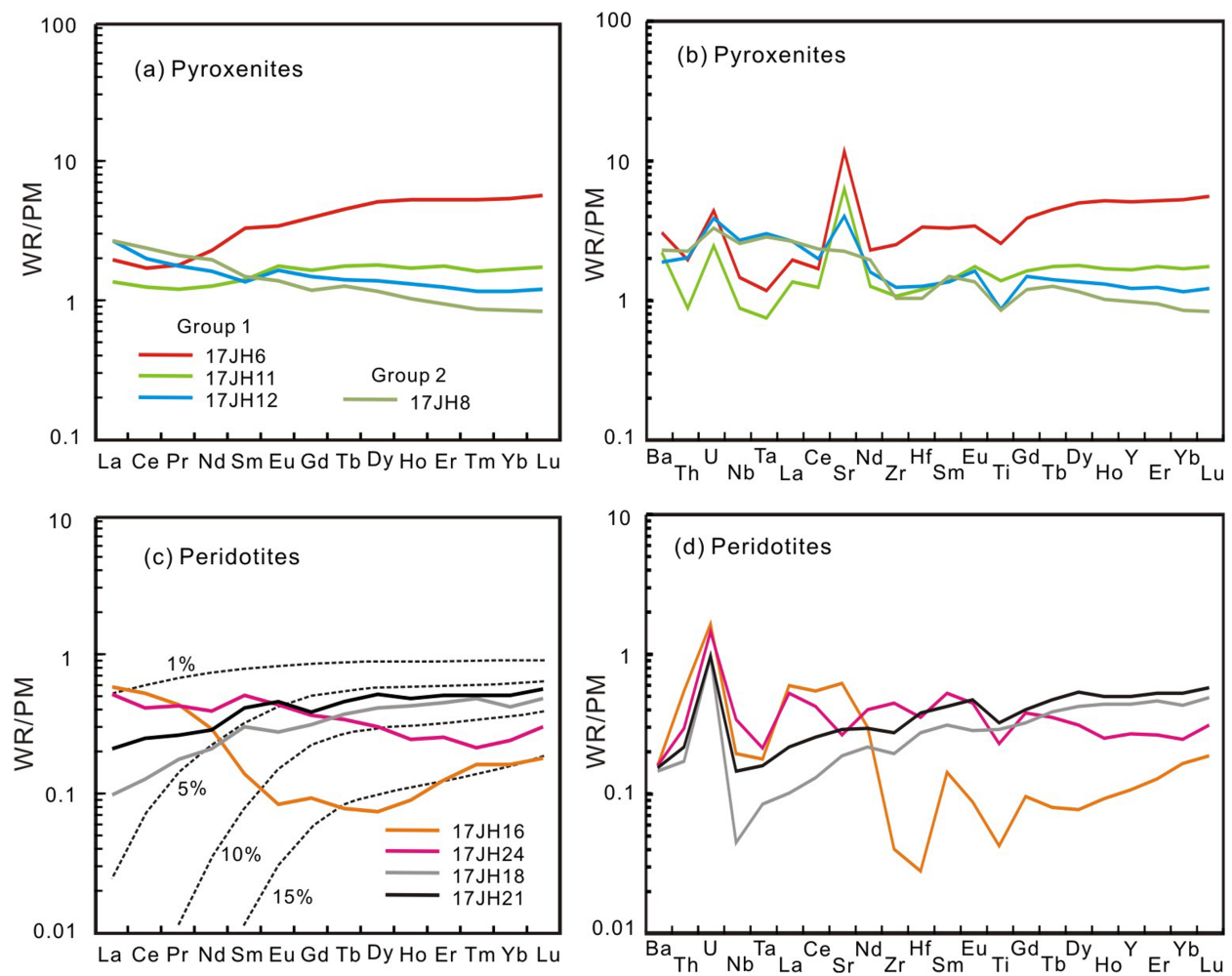

Figure 4. Primitive mantle (PM)-normalized (McDonough \& Sun, 1995) trace element patterns for whole rock (WR) of samples in this study. The residues of partial melting of PM at 1 to $15 \%$ calculated using a nonmodal fractional melting model (Takazawa et al., 2000) and parameters from Ionov et al. (2017) are shown for comparison.

\subsection{Oxygen Isotope Composition of Olivine}

The $\delta^{18} \mathrm{O}$ values for olivine are given in Table S5. Group 1 pyroxenites $17 \mathrm{JH} 6$ and $17 \mathrm{JH} 11$ have $\delta^{18} \mathrm{O}$ values of $4.75 \pm 0.12 \%$ o and $5.13 \pm 0.12 \%$, respectively. The former value is lower than the mantle olivine range (5.1-5.4\%o; Chazot et al., 1997; Mattey et al., 1994) but falls in the range reported for altered oceanic crust (0-12\%; Muehlenbachs, 1986). Olivines from other pyroxenites and all peridotite xenoliths have $\delta^{18} \mathrm{O}$ values of $5.13-5.38 \%$, that is, within the mantle olivine range (Figure 10).

\section{Discussion}

\subsection{Origin of Peridotites}

Peridotite xenoliths are commonly direct samples from the CLM; their modal and chemical variations are attributed to variable degrees of melt extraction, and in some cases to later metasomatism by different agents (Pearson et al., 2014). Plot of $\mathrm{Al}_{2} \mathrm{O}_{3}$ versus $\mathrm{FeO}$ in melting residues may constrain both pressure and melting degrees because $\mathrm{Al}_{2} \mathrm{O}_{3}$ is a robust melt extraction index while $\mathrm{FeO}$ contents are controlled by pressure (Herzberg, 2004). The peridotites reported here are residues after 15-25\% of batch partial melting at low pressures based on $\mathrm{Al}_{2} \mathrm{O}_{3}$ contents (1.2-2.9 wt.\%) and $\mathrm{Fe}-\mathrm{Al}$ relations compared with experimental data on melting of primitive mantle composition (Figure 3). We also evaluate melting degrees using the model of Takazawa et al. (2000) that is based on the mineral-melt partition coefficients of incompatible elements (e.g., HREE) during partial melting of fertile mantle. This model examines fractional partial melting and yields melting degrees of $5-15 \%$ for the peridotites in this study (Figure 4).

Some peridotites with the highest $\mathrm{Al}_{2} \mathrm{O}_{3}$, low to moderate $\mathrm{Mg \#}$ ol $(0.89-0.91)$, and $\mathrm{Cr}_{\mathrm{sp}}(0.09-0.17)$ contain LREE-depleted cpx and show no significant metasomatic overprints. The remaining peridotites, with low $\mathrm{Al}_{2} \mathrm{O}_{3}$ (1.2-2.2 wt.\%) and high $\mathrm{Mg} \#_{\mathrm{ol}}$ (0.91-0.92), contain cpx with low HREE and LREE-enriched patterns, and Ti-enriched spinel (Figure 7), that is, are cryptically metasomatized. 

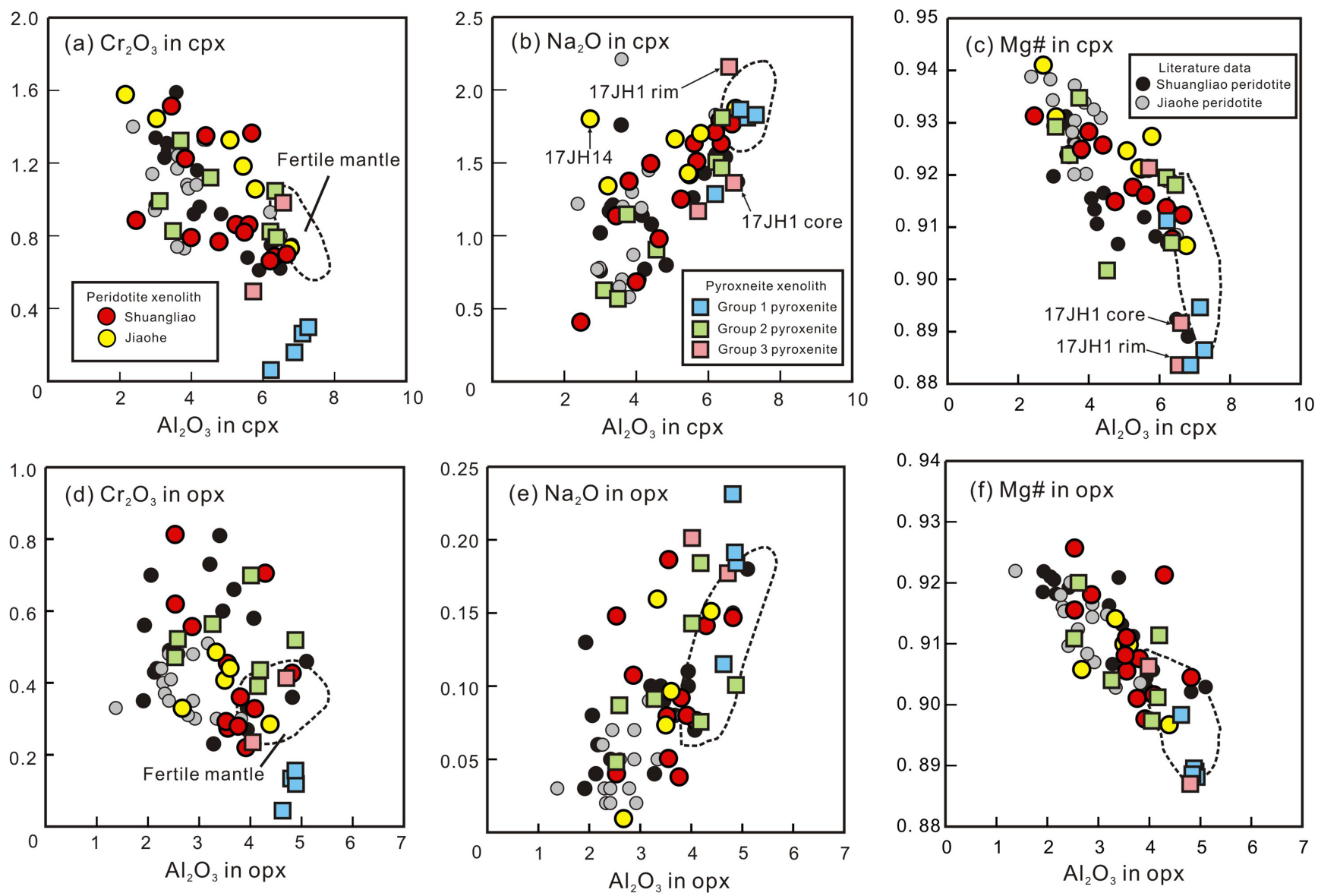

Figure 5. Covariation plots of $\mathrm{Cr}_{2} \mathrm{O}_{3}, \mathrm{Na}_{2} \mathrm{O}$ and $\mathrm{Mg} \#$ versus $\mathrm{Al}_{2} \mathrm{O}_{3}$ in clinopyroxene (cpx) and orthopyroxene (opx) in mantle xenoliths from Jiaohe and Shuangliao. Literature data are from Zhou et al. (2007) and Yu et al. (2009). The fields of fertile mantle are from data for Tariat in Central Asia (Ionov, 2007).

\subsection{Origin of the Pyroxenites}

Pyroxenites could be cumulates from mantle-derived melts (Bodinier et al., 1987; Downes, 2007; Irving, 1980; Lee et al., 2006), recycling of subducted oceanic crust (Allègre \& Turcotte, 1986; Kornprobst et al., 1990; Yu et al., 2010) or, alternatively, products of melt-peridotite interaction (Garrido \&

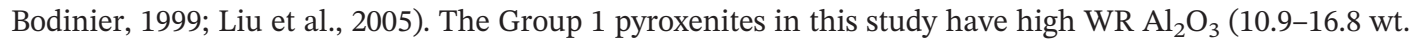
$\%$ ) and $\mathrm{CaO}$ (8.9-13.5 wt.\%), and minor positive Eu and Sr anomalies in the WR and cpx (Figures 4b, 6a, and $6 \mathrm{~b}$ ), indicating that plagioclase-rich protoliths could be their precursors. This suggestion is examined in a pseudo-ternary system [olivine-Ca-Tschermak (CaTS)-quartz] projected from diopside (Figure 11; Herzberg, 2011; Lambart et al., 2013). The enstatite (En)-CaTs junction separates the projection into silica-excess (right) and silica-deficient (left) sides. In the projection, the Group 1 pyroxenites plot on the silica-deficient side, consistent with the occurrence of olivine. By contrast, garnet pyroxenites reported by Yu et al. (2010) contain no olivine and show a trend toward the silica-excess side, and some of them resemble experimental residues after partial melting of eclogite (Yaxley \& Green, 1998).

The compositions of the Group 1 pyroxenites are distinct from those of gabbroic rocks in subducted oceanic crust (Bach et al., 2001) and of experimental residues of eclogite melting (Figure 11). This argues against an origin by metamorphism of gabbroic protoliths suggested by Yu et al. (2010). In addition, the Group 1 pyroxenites have higher Mg\# $(0.86-0.87)$ and $\mathrm{Ni}(600-780 \mathrm{ppm})$ than cumulates from eclogite-derived melts ( $\mathrm{Mg} \#<0.84, \mathrm{Ni}<520$ ppm; Montanini et al., 2012; Montanini \& Tribuzio, 2015).

Here, we suggest an alternative origin for the Group 1 pyroxenites by reaction of melts extracted from subducted crust with surrounding peridotites at high melt/peridotite ratios, while silica-excess garnet 

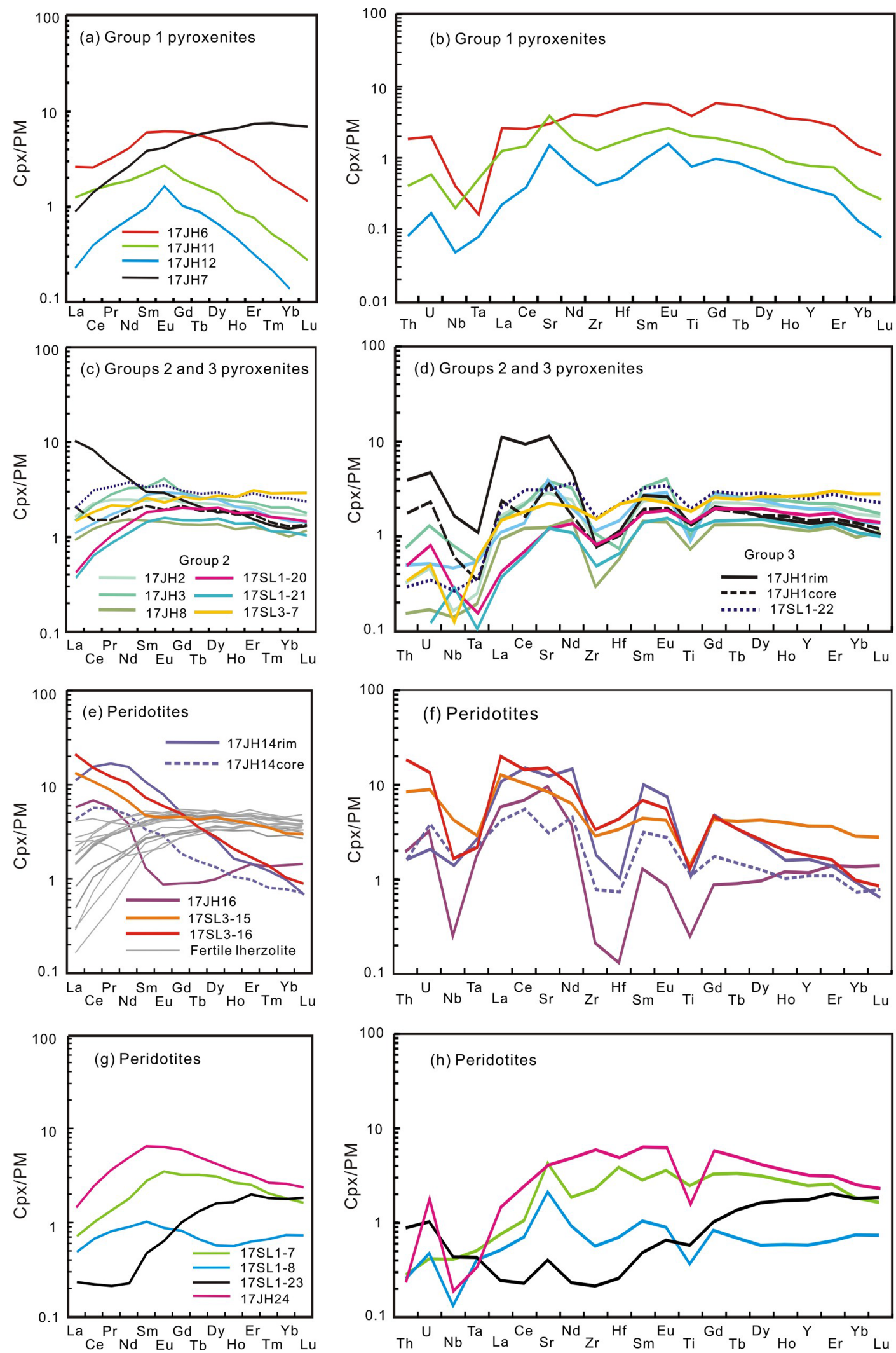

Figure 6. Trace element patterns for clinopyroxenes (Cpx) normalized to primitive mantle from samples in this study (McDonough \& Sun, 1995). 


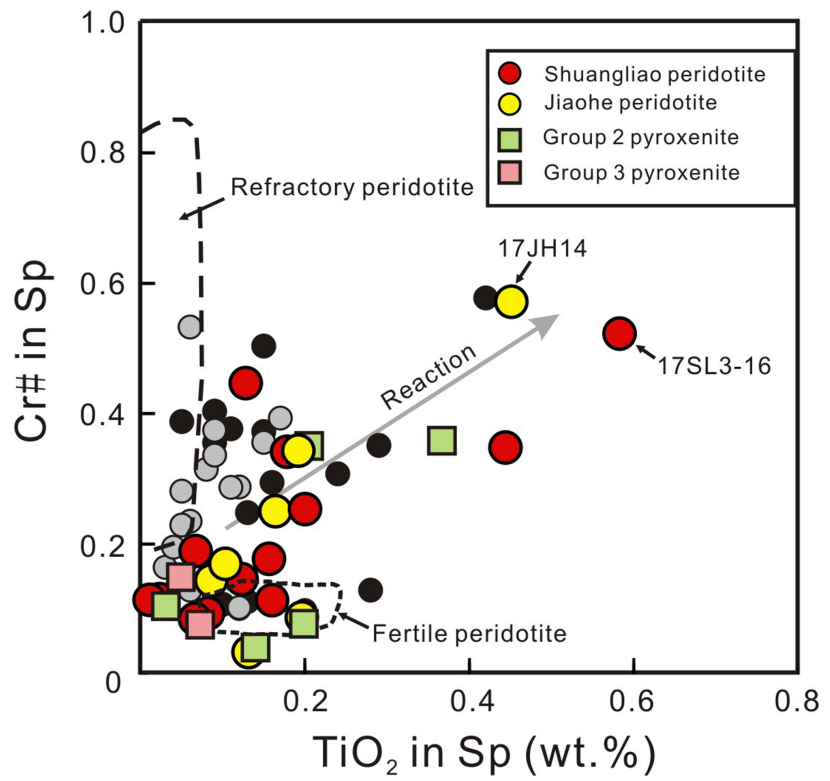

Figure 7. A plot of $\mathrm{TiO}_{2}$ versus $\mathrm{Cr} \#$ in spinel from Jiaohe and Shuangliao xenoliths in this study and from the literature (Yu et al., 2009; Zhou et al., 2007). The field for fertile mantle is for Tariat in central Asia (Ionov, 2007); the field refractory peridotites is after Doucet et al. (2012). pyroxenites from Yu et al. (2010) may be residues after partial melting of recycled subducted crust. Such reactions consume olivine in the peridotites (Herzberg, 2011; Sobolev et al., 2005) to increase Ni concentrations in residual olivine, which is incorporated in group 1 pyroxenites, consistent with high $\mathrm{Ni}(3,190-3,388 \mathrm{ppm})$ in olivine in these samples.

Group 2 pyroxenites contain rare spinel and no garnet and have distinct mineral compositions (Figures 5 and 6). They cannot be the recycled gabbroic rocks or cumulates crystallized from eclogite- or peridotite-derived melts because of (i) low WR $\mathrm{Al}_{2} \mathrm{O}_{3}$ (5.4 wt.\%) and high $\mathrm{Mg \#} \mathrm{(0.89),} \mathrm{(ii)}$ high $\mathrm{Mg} \#$ in pyroxenes $\left(\mathrm{Mg} \#_{\mathrm{cpx}}=0.89-0.92 ; \mathrm{Mg}_{\mathrm{opx}}=0.87-0.91\right)$, and (iii) cpx REE patterns distinct from LREE-enriched patterns of cumulate pyroxenites. The mineral and geochemical features of Group 2 pyroxenites are strongly reminiscent of those observed in the (ol) websterites from Ronda and Beni Bousera orogenic peridotites (Bodinier \& Godard, 2014, and references therein). In the Beni Bousera orogenic peridotite massif, the (ol) websterite layers were found in the outer part of the garnet clinopyroxenite layers, and the contacts of (ol) websterite to host peridotite are generally diffuse (Chetouani et al., 2016). Based on this field evidence, several recent studies proposed a garnet pyroxenite-peridotite reaction model for the generation of the (ol) websterite (e.g., Varas-Reus et al., 2016). However, such direct contact between garnet clinopyroxenites (Group 1) and Group 2 pyroxenites has not been found in the mantle xenoliths from our study and literature in NE China. Thus, the peridotite-pyroxenite model seems too speculative for the formation of Group 2 pyroxenites in this study. Instead, we suggest that the Group 2 pyroxenites formed by melt-rock reactions (Kelemen et al., 1998; Liu et al., 2005) based on the following lines of evidence. (1) Major element compositions of cpx and opx in Group 2 pyroxenites overlapping with those in mantle peridotites (Figure 5). (2) Transition from peridotite to websterite in composite xenoliths 17JH5 and 17SL1-20 (Figure 2h), with cpx in the websterite containing fine-grained pockets of olivine, opx, and spinel (Figure 2i), which may be peridotite relics. Reactions between peridotite and silica-poor basaltic melt commonly result in the dissolution of opx and the precipitation of ol. Such reactions have been well documented by experimental studies (Daines \& Kohlstedt, 1994; Morgan \& Liang, 2003; Tursack \& Liang, 2012) and can account for the formation of dunite in ophiolites (Morgan et al., 2008; Suhr et al., 2003). In order to form the Group 2 pyroxenites by melt-peridotite reactions, a silica-rich melt is required (Lambart et al., 2012; Wang et al., 2016; Yaxley \& Green, 1998). The inferred melt was most likely derived from the recycled oceanic crust and had been modified by the reactions forming
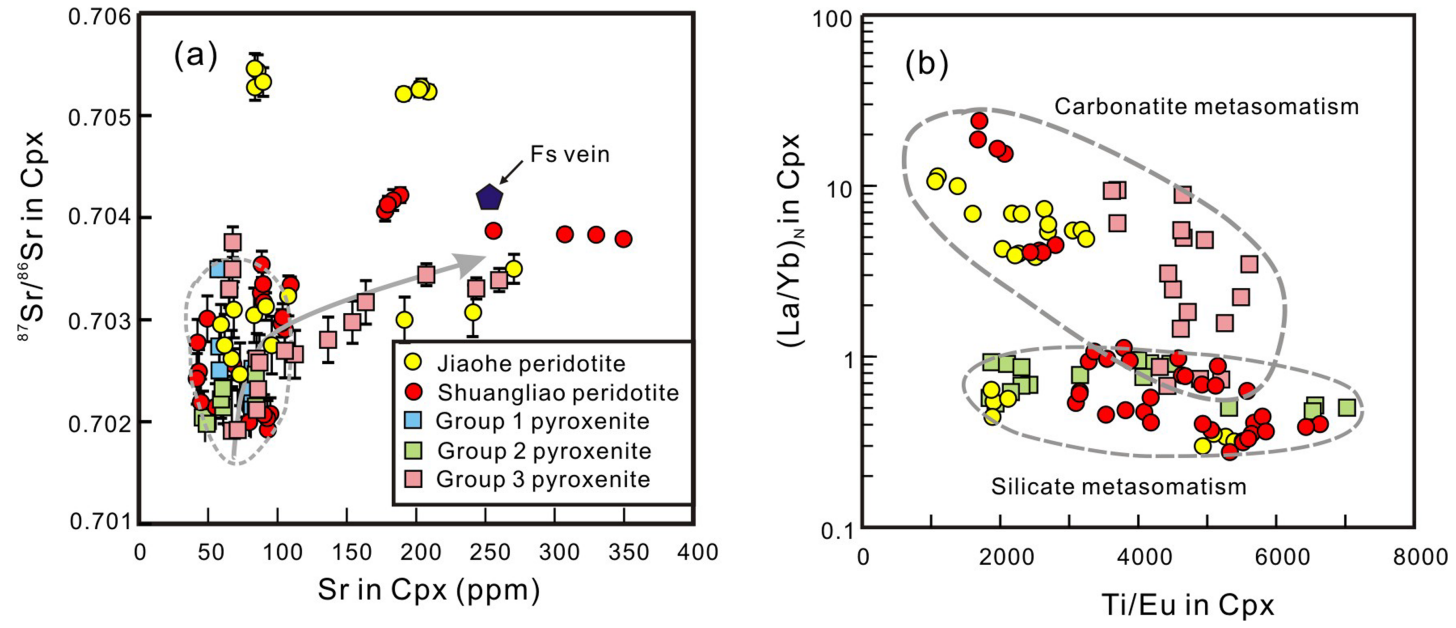

Figure 8. Plots of ${ }^{87} \mathrm{Sr} /{ }^{86} \mathrm{Sr}$ versus $\mathrm{Sr}$ concentrations (a) and $(\mathrm{La} / \mathrm{Yb})_{\mathrm{N}}$ versus $\mathrm{Ti} / \mathrm{Eu}(\mathrm{b})$ in clinopyroxene (Cpx). 

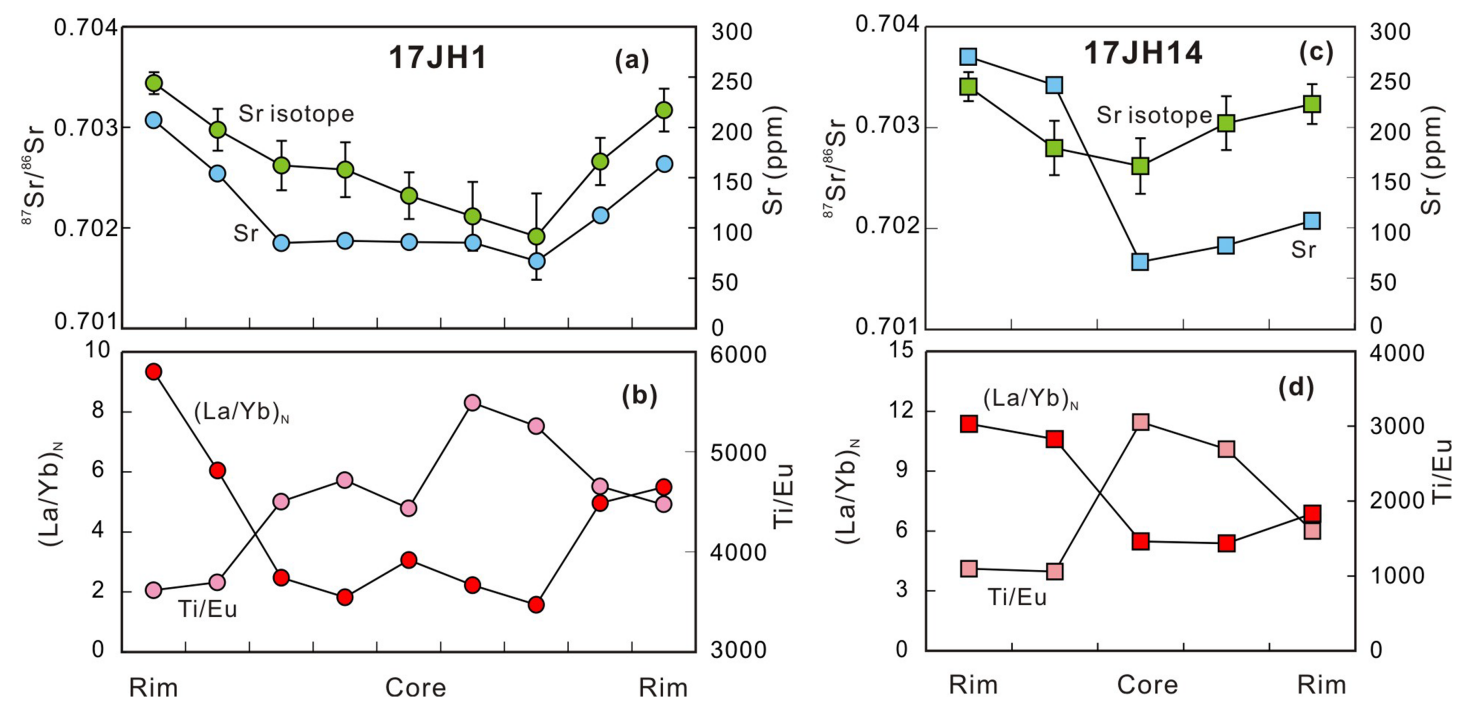

Figure 9. Variations of Sr concentrations, ${ }^{87} \mathrm{Sr} /{ }^{86} \mathrm{Sr},(\mathrm{La} / \mathrm{Yb})_{\mathrm{N}}$, and Ti/Eu across Cpx grains in samples 17JH1 (a and b) and 17JH14 (c and d).

the Group 1 pyroxenites. Owing to preferential incorporation of $\mathrm{Al}_{2} \mathrm{O}_{3}$ and $\mathrm{HREE}$ in garnet, the reacted melt after the formation of Group 1 pyroxenites has low $\mathrm{Al}_{2} \mathrm{O}_{3}$ and HREE; its ascending and reaction with the lithospheric peridotite could produce the Group 2 pyroxenites. Therefore, we conclude that the reacting melts in Groups 1 and 2 pyroxenites share a common source, that is, recycled subducted crust, which is consistent with the similar whole rock trace element patterns (Figure 4b) and Sr isotopic compositions (Figure 8a) for the Groups 1 and 2 pyroxenites.

Group 3 pyroxenites are similar in mineral characteristics to the Group 2 pyroxenites and formed by silicate melt-peridotite reactions as well. However, the compositional zoning in cpx of 17JH1 and unique reaction rims around opx (fine-grained olivine and cpx) in 17SL1-22 require additional melt infiltration after their primitive formation.

\subsection{Metasomatic Melt Compositions}

Here, we constrain the compositions of metasomatic melts that reacted with peridotites to produce wehrlites and Group 3 pyroxenites in the lithospheric mantle beneath NE China. Mantle wehrlites are commonly thought to form by reaction of harzburgite or lherzolite precursors with carbonatite (Yaxley et al., 1991) or volatile-rich silicate melts (Ionov et al., 2005; Xu et al., 1996). Interaction with carbonatite melts may
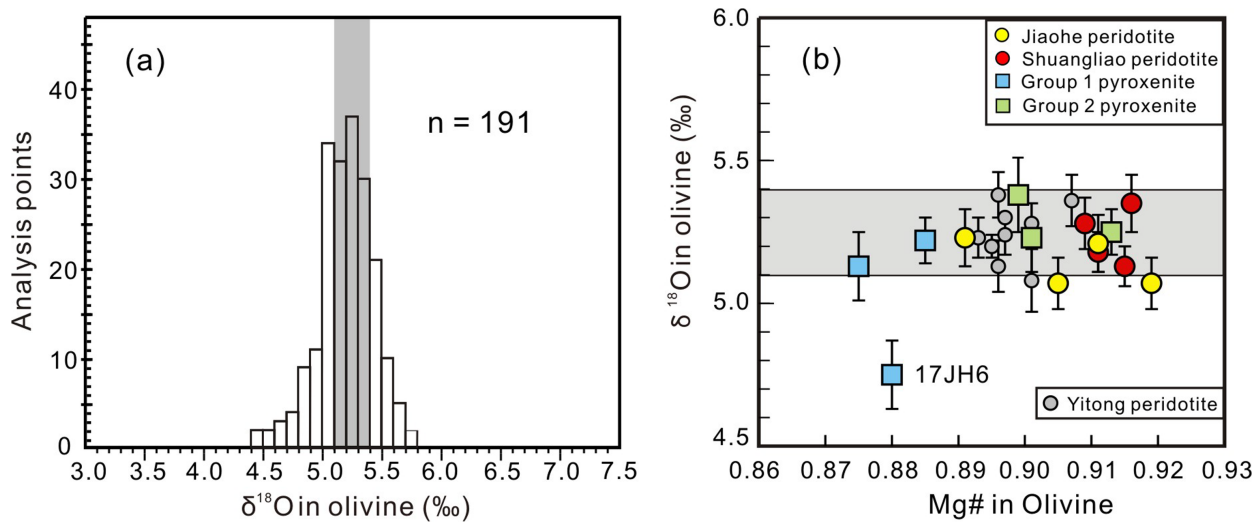

Figure 10. (a) A histogram for $\delta^{18} \mathrm{O}$ values in olivine from mantle xenoliths in this study. (b) A plot of $\delta^{18} \mathrm{O}$ versus $\mathrm{Mg \#}$ in olivine. The gray field represents typical mantle $\delta^{18} \mathrm{O}$ values (5.1-5.4; Chazot et al., 1997; Mattey et al., 1994). Also shown are data for peridotite xenoliths from nearby Yitong locality (Xu et al., 1996). 


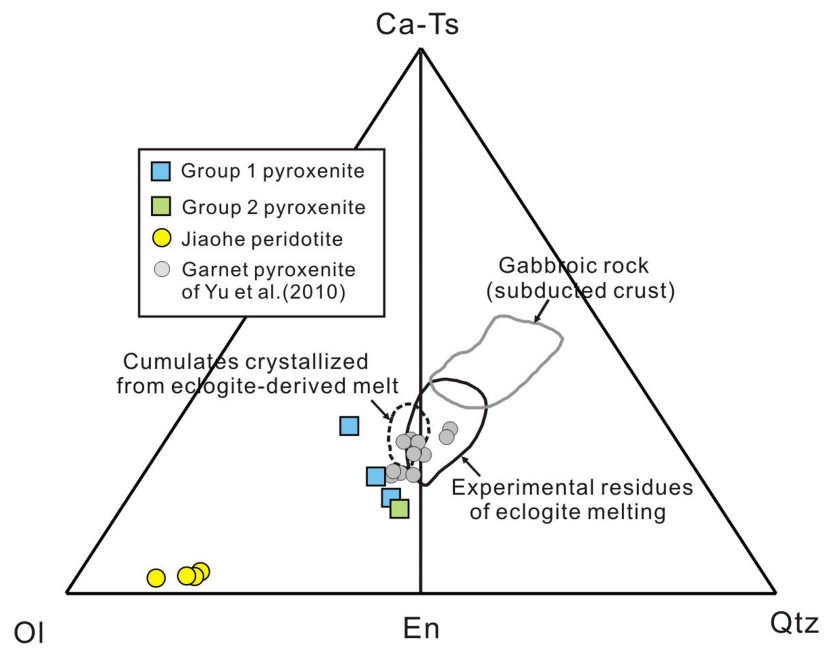

Figure 11. Jiaohe xenoliths in a projection of the pseudo-ternary system olivine (Ol)-Ca-Tschermak component (CaTS)-quartz (Qtz)

(Herzberg, 2011). Also shown are gabbroic rocks from lower oceanic crust at the southwestern Indian Ridge (Bach et al., 2001), experimental residues of different partial melting degrees of eclogite (Yaxley \& Green, 1988), and cumulates crystallized from eclogite-derived melts (Montanini et al., 2012; Montanini \& Tribuzio, 2015).

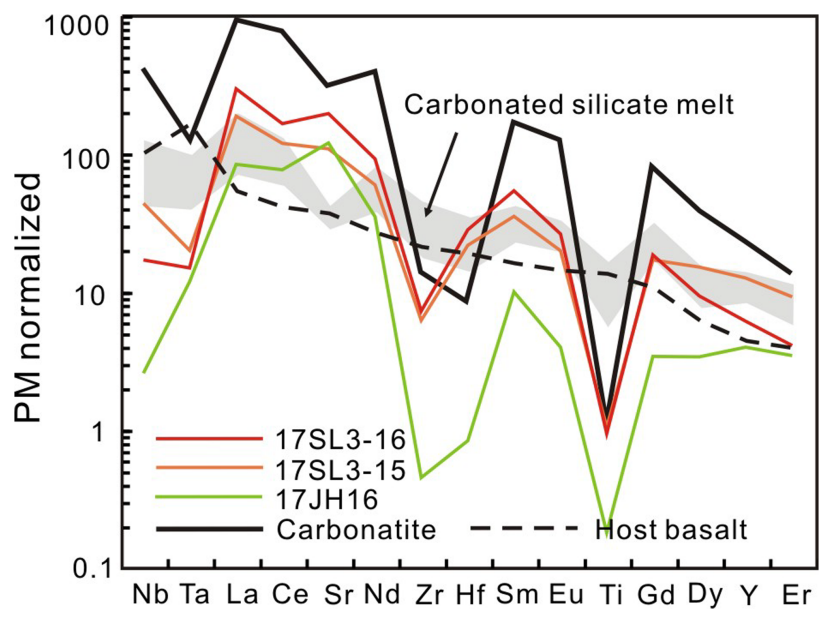

Figure 12. Trace element compositions of hypothetical melts in equilibrium with LREE-enriched clinopyroxenes using partition coefficients from Klemme et al. (1995). Also shown are the composition of carbonatites (Chen et al., 2016 and references therein), natural carbonated silicate melts (Zhang et al., 2017), and host basalts (Xu et al., 2012). produce LREE and Sr enrichments without significantly affecting Mg\# (Green \& Wallace, 1988), whereas metasomatism by evolved silicate melts results in decreasing Mg\# (Ionov et al., 2005; Xu et al., 1996).

Wehrlite in this study has $\mathrm{Mg}$-rich minerals $\left(\mathrm{Mg} \#_{\mathrm{cpx}}=0.94 ; \mathrm{Mg}_{\mathrm{ol}}=0.92\right)$ as well as high $\mathrm{Na}_{2} \mathrm{O}\left(1.81\right.$ wt.\%) and $\mathrm{K}_{2} \mathrm{O}(0.14$ wt.\%) in cpx. The cpx is zoned with increasing $(\mathrm{La} / \mathrm{Yb})_{\mathrm{N}}$ and $\mathrm{Sr}$ and decreasing Ti/Eu from core to rim (Figure 9). This suggests that the metasomatic melt was rich in $\mathrm{Mg}$, Na, K, Sr, and LREE and had low Ti/Eu, that is, being a composition typical for dolomitic carbonatite melt (Green \& Wallace, 1988; Rudnick et al., 1993; Yaxley et al., 1991). Experimental work has shown that such melt at pressures $<2.1 \mathrm{GPa}$ can convert lherzolite to wehrlite with magnesian olivine and cpx (Green \& Wallace, 1988), consistent with the inferred wehrlite formation in this study. Three peridotites (17SL3-15, 17SL3-16, and 17JH16) contain LREE-enriched cpx as well (Figure 6e) and could have been affected by a similar process. For instance, significant HFSE (Zr, Hf, and $\mathrm{Ti}$ ) depletions in whole rock (Figure 4d) and a high $\mathrm{Ca} / \mathrm{Al}$ ratio in whole rock sample $17 \mathrm{JH} 16$ indicate a metasomatism by carbonatite melt.

Trace element compositions of melts in equilibrium with metasomatic cpx are estimated here using cpx/melt partition coefficients of Klemme et al. (1995). The hypothetical melts are enriched in Sr and LREE and depleted in Nb, Zr, Hf, and Ti, akin to carbonatites (Figure 12). Such melts could produce the LREE-enriched cpx patterns in this study. The remaining metasomatized peridotites (17SL1-7, 17SL1-8, 17SL1-23, and 17JH24) have cpx with low LREE concentrations, high Ti/Eu ratios (Figures $6 \mathrm{~g}$ and $8 \mathrm{~b}$ ) and no significant HFSE (Nb, Ta, Zr, and Hf) depletions. In addition, whole rock trace element patterns for Sample 17JH24 have no significant HFSE depletions (Figure 4d). These observations rule out carbonatite melts as metasomatic agents and are more indicative of metasomatism by silicate melts. Sample 17SL1-23 has a recrystallized microstructure and high modal opx (43\%), which could result from interaction with mafic melts at high melt/rock ratios (Kelemen et al., 1998; Xu et al., 2003). Many Shuangliao and Jiaohe peridotites from the literature show Fe enrichments (Figure 4), likely due to reactions with evolved mafic melts (Ionov et al., 2005).

The petrologic and chemical characteristics of the Group 3 pyroxenites suggest additional melt infiltration after their formation by silicate melt-peridotite reactions. For instance, zoned cpx in sample 17JH1 shows gradual increases in $\mathrm{Na}_{2} \mathrm{O},(\mathrm{La} / \mathrm{Yb})_{\mathrm{N}}$, and $\mathrm{Sr}$ and a decrease in $\mathrm{Ti} / \mathrm{Eu}$ from core to rim, which leads us to suggest that this pyroxenite experienced a metasomatic overprint by carbonatite melt after the silicate metasomatism. Furthermore, Sample 17SL1-22 has more spinel than Group 2 pyroxenites $(2.2 \%$ vs. $\leq 0.5 \%)$ and contains opx surrounded by fine-grained olivine and low-Al cpx (Figure 3b), which could be attributed to infiltration of a carbonatite melt (Green \& Wallace, 1988) shortly before the eruption of host magma (e.g., Ionov et al., 1994).

K-rich (3.9-8.6 wt.\% $\mathrm{K}_{2} \mathrm{O}$ ) accessory feldspars have been found in both the garnet-bearing (Group 1) and garnet-free (Groups 2 and 3) pyroxenites. The feldspars occur along grain boundaries, as crosscutting veins or inclusions in pyroxenes. These feldspars are similar in texture and chemistry to those in peridotite xenoliths from Sikhote-Alin in Russian Far East (Ionov et al., 1999), which is close to the sampling region in this study. The feldspars cannot represent equilibrium assemblages in the Groups 1 and 2 pyroxenites and were unrelated to the origin of these pyroxenites. By contrast, Ionov et al. (1999) attributed feldspar formations to recent infiltration of an alkali-rich, $\mathrm{H}_{2} \mathrm{O}$-poor fluid to the xenoliths. As shown in 
Figure 2d, the feldspars (with $8.6 \mathrm{wt} . \% \mathrm{~K}_{2} \mathrm{O}, 0.2 \mathrm{wt} . \% \mathrm{CaO}$ ) occur as inclusions in cpx of Group 3 pyroxenites, suggesting that both feldspars in this study and late-stage cpx were formed at the same stage of metasomatism due to recent infiltration of a K-rich carbonatite melt.

\subsection{The Sources of the Metasomatic Melts}

Strontium and $\mathrm{O}$ isotopic compositions of metasomatic minerals may provide robust constraints on the sources of metasomatic agents. The $\delta^{18} \mathrm{O}$ of olivine in Group 1 pyroxenite 17JH6 (4.75 $\pm 0.12 \%$ o is significantly lower than the range for mantle-derived olivine (5.1-5.4\%o; Chazot et al., 1997; Mattey et al., 1994) but is within the range of altered oceanic crust (0-12\%o; Muehlenbachs, 1986). Thus, it appears that recycled crustal materials were incorporated in the Group 1 pyroxenites, consistent with textural and chemical data discussed in this study.

The ${ }^{87} \mathrm{Sr} /{ }^{86} \mathrm{Sr}$ ratios of the cpx in the Groups 1 and 2 pyroxenites range from 0.7020 to 0.7035 . This range is lower than the whole rock ${ }^{87} \mathrm{Sr} /{ }^{86} \mathrm{Sr}$ variations (0.7036-0.7042) for Jiaohe garnet pyroxenites reported by $\mathrm{Yu}$ et al. (2010). If the latter represents residues after partial melting of recycled subducted crust (and presuming that the ${ }^{87} \mathrm{Sr} /{ }^{86} \mathrm{Sr}$ ratios of the pyroxenites have not evolved much since their formation because they have low $\mathrm{Rb} / \mathrm{Sr}$ ratios), the resultant melts had the same ${ }^{87} \mathrm{Sr} /{ }^{86} \mathrm{Sr}$ range at the time of melting. The discrepancy in ${ }^{87} \mathrm{Sr} /{ }^{86} \mathrm{Sr}$ ratios between cpx in the Groups 1 and 2 pyroxenites and the WR of pyroxenites reported by Yu et al. (2010) can be attributed to either (1) feldspars with higher $\mathrm{Sr}$ contents and ${ }^{87} \mathrm{Sr} /{ }^{86} \mathrm{Sr}$ ratios in these pyroxenites or (2) the ${ }^{87} \mathrm{Sr} /{ }^{86} \mathrm{Sr}$ ratios of $\mathrm{cpx}$ in these pyroxenites resulting from mixing of peridotites $\left({ }^{87} \mathrm{Sr} /{ }^{86} \mathrm{Sr} \leq 0.7023\right)$ and melts extracted from recycled subducted crust $\left({ }^{87} \mathrm{Sr} /{ }^{86} \mathrm{Sr}=0.7036-0.7042\right)$.

Clinopyroxene grains in Group 3 pyroxenite 17JH1 and wehrlite 17JH14 metasomatized by carbonatite melts (section 5.3) show gradual increases in ${ }^{87} \mathrm{Sr} /{ }^{86} \mathrm{Sr}$ ratios from cores $(0.7019-0.7026)$ to rims $(\sim 0.7034$; Figure 9). The cpx from another Group 3 pyroxenite $(17 \mathrm{SL} 1-22)$ has ${ }^{87} \mathrm{Sr} /{ }^{86} \mathrm{Sr}$ ratios of $0.7033-0.7038$. The feldspar in $17 \mathrm{JH} 1$ with an ${ }^{87} \mathrm{Sr} /{ }^{86} \mathrm{Sr}$ ratio of 0.7042 formed by melt-rock reaction. These observations suggest that the metasomatic carbonatite melt had a ${ }^{87} \mathrm{Sr} /{ }^{86} \mathrm{Sr}$ ratio of $\geq 0.7042$, which is distinct from the values for normal depleted mantle (0.7026; Carlson \& Ionov, 2019; Workman \& Hart, 2005) and for the CLM beneath these regions (Yu et al., 2009), but falls in the range for altered oceanic slab (0.7036-0.7074; Staudigel et al., 1995). It may appear from the Sr isotopic data that the metasomatic carbonatite could be linked to subducted slab. However, the inferred carbonatite melts are K-rich, comparable to the Cenozoic potassic basalts in NE China (Tian et al., 2016). The potassic basalts have geochemical characteristics typical of carbonatite metasomatism (e.g., high $\mathrm{CaO} / \mathrm{Al}_{2} \mathrm{O}_{3}$ and $\mathrm{La} / \mathrm{Yb}$, and significant HSFE depletions) and were documented to be derived from carbonated asthenosphere (Tian et al., 2016; Wang, Chen, et al., 2017). It is thus most likely that the carbonatite melts in this study originated from the mantle origin, like the potassic basalts, rather than from a subducted slab. In addition, carbonatite melts produced by partial melting of subducted slab are calcium-rich (Hammouda, 2003), inconsistent with our inference in the previous section that the metasomatic melts were dolomitic.

Another argument against the provenance of the metasomatic melts from a subducted slab is mantle-like $\delta^{18} \mathrm{O}$ in olivine from the metasomatized xenoliths (5.07-5.35\%; Figure 10). Although mantle-like $\delta^{18} \mathrm{O}$ values in melts do not necessarily imply that these melts originated from the mantle (Bindeman et al., 2005), carbonatite melts derived from subducted slabs much likely have high $\delta^{18}$ O values (e.g., Miller et al., 2001). Such example is presented by clinopyroxenite xenoliths from Hannuoba in the northern NCC, which have remarkably high whole rock $\delta^{18} \mathrm{O}$ values (9.9-11.3\%; Hu et al., 2019). These xenoliths are results of reactions between mantle peridotite and melts derived from subducted slab. The direct evidence is presented by carbonatites intruding the Hannuoba basalts. These carbonatites have high $\delta^{18} \mathrm{O}$ values $(22-23 \%$ ) and are believed to form by melting of subducted sedimentary carbonates (Chen et al., 2016). The Hannuoba data mentioned above suggest that the carbonatite melt derived from partial melting of a slab in NE China should have high $\delta^{18} \mathrm{O}$. Reaction products of peridotite with such slab-derived carbonatite melts unlikely maintain the typical mantle olivine $\delta^{18} \mathrm{O}$ values in our samples. Instead, the metasomatic melts can be from carbonated asthenosphere. Experimental studies suggest that low-degree partial melting of carbonated mantle peridotites produces carbonatite melts in a broad pressure range $(0.2-10 \mathrm{GPa}$; Dasgupta \& Hirschmann, 2006; Foley et al., 2009; Wallace \& Green, 1988). 
Late Cretaceous and Cenozoic basalts in eastern China have ${ }^{87} \mathrm{Sr} /{ }^{86} \mathrm{Sr}$ ratios of $0.7031-0.7056$ (Li et al., 2017), overlapping the Sr isotopic composition of the metasomatic agent inferred for the xenoliths. These basalts also show anomalously low $\delta^{26} \mathrm{Mg}(-0.6$ to $-0.3 \%$ ), for example, -0.50 to $-0.33 \%$ in Shuangliao, which have been attributed to recycling of sedimentary carbonates from the Pacific slab into their asthenospheric sources (Li et al., 2017; Tian et al., 2016). The same process could also be responsible for the enrichment of the asthenosphere beneath eastern China in $\mathrm{CO}_{2}$ and $\mathrm{H}_{2} \mathrm{O}$ (Li et al., 2017; Xi et al., 2019). Low-degree melting of such sources could yield carbonatite melt like metasomatic media inferred from our xenoliths.

The carbonatite metasomatism took place shortly before the xenoliths were carried to the surface by host magma because chemical and isotope mineral zoning disappears over time due to diffusion. Using the value of Sr diffusivity in cpx from Sneeringer et al. (1984) at $1,000^{\circ} \mathrm{C}$, a cpx grain with diameter of $1 \mathrm{~cm}$ may only preserve its Sr isotopic zoning for $<30 \mathrm{Ma}$. The cpx grain size in 17JH1 is smaller $(\sim 5 \mathrm{~mm})$, and equilibration temperature is higher $\left(1,026^{\circ} \mathrm{C}\right)$, such that a period much shorter than $30 \mathrm{Ma}$ is required for its homogenization. This suggests that the carbonatite metasomatism most likely occurred during the Cenozoic, that is, roughly coeval with the eruption of host basaltic magmas.

\subsection{Effects of Mantle Upwelling Versus Recycling of Oceanic Components on the CLM Beneath Northeastern China}

The westward subduction of the Pacific slab had induced the destruction of the cratonic root in the eastern NCC (Zhu et al., 2012) and the formation of the Songliao basin in NE China (Feng et al., 2010). However, how materials from the subducted slab have modified the CLM beneath eastern China remain unclear. Moreover, some domains in the region appear to have been little affected by the subduction (Ionov et al., 2020).

Several publications (e.g., Deng et al., 2017; Xu, Pei, et al., 2013) proposed that melts/fluids were transported to the base of the CLM directly from the Pacific slab and tried to link the metasomatism in the peridotites to the subduction. Their inferences were based on relatively high ${ }^{87} \mathrm{Sr} /{ }^{86} \mathrm{Sr}$ ratios $(0.7033-0.7055)$ in the peridotites that overlap the values of subducted oceanic components (Staudigel et al., 1995). However, such an explanation for elevated ${ }^{87} \mathrm{Sr} /{ }^{86} \mathrm{Sr}$ ratios is not unambiguous. High ${ }^{87} \mathrm{Sr} /{ }^{86} \mathrm{Sr}$ ratios are common in refractory mantle peridotites all over the world from a range of craton and off-craton settings (Pearson et al., 2014) and can be attributed to radiogenic ${ }^{87} \mathrm{Sr}$ ingrowth in ancient metasomatized mantle (e.g., Walker et al., 1989). Our results suggest that melts derived from carbonated asthenosphere may also have Sr isotopic compositions similar to those in slab materials. Moreover, high-resolution $P$ wave tomography shows that the subducting Pacific slab is stagnant in the mantle transition zone beneath northeastern China (Huang \& Zhao, 2006; Wei et al., 2015). Based on temporal-spatial distribution pattern of the late Mesozoic magmatism and geochemical characteristics of Mesozoic-Cenozoic basalts in eastern Asian continental margin, it is commonly accepted that the subducted slab was stagnant in the mantle transition zone before $106 \mathrm{Ma}$ (e.g., Li et al., 2017; Zhu et al., 2012). In contrast to melts/fluids that were extracted from the Pacific slab during its subduction and directly transported to the CLM base, it is more likely that the recycled oceanic components remaining in the slab were first subducted to deep mantle and then incorporated to the asthenosphere (Wang, Xu, et al., 2017).

This hypothesis provides a reasonable model for the origin of pyroxenites in this study and of garnet pyroxenites reported by Yu et al. (2010). Recycled gabbroic crust was preserved in the asthenosphere as eclogites (Xu et al., 2012). Upwelling of the asthenosphere, as identified by recent geophysical observations (Guo et al., 2016; Tang et al., 2014), would result in eclogite melting due to their lower melting point than peridotite. The partial melting residues formed the garnet pyroxenites of $\mathrm{Yu}$ et al. (2010), while the reactions between melts extracted from the crust stored in the asthenosphere and peridotites would produce the pyroxenites in this study. Subsequent partial melting of carbonated peridotites could produce carbonatite melts that migrated upward and metasomatized the overlying CLM.

$\mathrm{Xu}$ et al. (2003) reported reactive, recrystallized harzburgites from Huinan, northeastern NCC, a location close to the sampling region in this study (Figure $1 \mathrm{~b}$ ). The mineral and chemical compositions of these harzburgites deviate from partial melting trends of residual peridotites but are more indicative of an origin by reaction between lherzolites and basaltic melts derived from upwelling asthenosphere (Xu et al., 2003). Metasomatized peridotites from other sites in northeastern China, for example, Yitong (Xu et al., 1996) 
and Fuxin (Wang et al., 2018), have olivine with mantle-like O isotopic compositions. These results, combined with the isotopic data in this study, suggest that the contribution of mantle upwelling was greater than that of crustal recycling in the evolution of lithospheric mantle beneath northeastern China.

\section{Conclusions}

The evolution of the CLM beneath northeastern China is constrained by a comprehensive study on pyroxenite and peridotite xenoliths in Cenozoic basalts at Jiaohe and Shuangliao. Three groups of pyroxenites are identified. Group 1 pyroxenites with high $\mathrm{Al}_{2} \mathrm{O}_{3}$ and $\mathrm{Ni}$, moderate $\mathrm{Mg} \#$, positive $\mathrm{Eu}$ and $\mathrm{Sr}$ anomalies, and olivine $\delta^{18} \mathrm{O}$ of $4.8-5.1 \%$ were formed by reaction of peridotites with melts extracted from subducted crust. Group 2 pyroxenites have peridotite-like compositions of pyroxenes and were formed by reactions of lithospheric peridotites with melts derived from recycled crust that had been modified by the formation of Group 1 pyroxenites. Group 3 pyroxenites contain orthopyroxene surrounded by fine-grained olivine and clinopyroxene or have chemically zoned clinopyroxene, which resulted from recent infiltration of a carbonatite melt originated from carbonated asthenosphere. The peridotites comprise moderately refractory lherzolites and various metasomatized rocks including a wehrlite. The clinopyroxene grains in the wehrlite have high $\mathrm{Mg \#}$ and $\mathrm{Na}_{2} \mathrm{O}$, chemical and $\mathrm{Sr}$ isotopic zoning, consistent with recent infiltration of a dolomitic carbonatite melt. Our results suggest that subducted crustal materials were initially transported to the asthenosphere beneath northeastern China to produce carbonate-bearing domains. Upwelling of the carbonated asthenosphere produced carbonatite melts that migrated upward and metasomatized the overlying lithospheric mantle.

\section{Acknowledgments}

P. G. acknowledges a fellowship from China Scholarship Council as a joint PhD student at the Montpellier University, France. D. A. I. acknowledges funding from the Chinese Academy of Sciences President's International Fellowship Initiative (PIFI) for Visiting Scientists in 2017 and in 2019. We thank journal editors Dr. Stephen Parman and Dr. John Lassiter and two anonymous reviewers for their constructive comments and suggestions. This work was financially supported by the National Natural Science Foundation of China (Grant 91858211) and National Key Research and Development Project (2017YFC0601304). The data for the present study are archived at Mendeley Data (https://doi.org/10.17632/ 2jpg54nvsc.4).

\section{References}

Allègre, C., \& Turcotte, D. L. (1986). Implications of a two-component marble-cake mantle. Nature, 323, $123-126$.

Bach, W., Alt, J. C., Niu, Y., Humphris, S. E., Erzinger, J., \& Dick, H. J. B. (2001). The geochemical consequences of late-stage low grade alteration of lower ocean crust at the SW Indian Ridge: Results from ODP Hole 735B (Leg 176). Geochimica et Cosmochimica Acta, 65, 3267-3287.

Bindeman, I. N., Eiler, J. M., Yogodzinski, G. M., Tatsumi, Y., Stern, C. R., Grove, T. L., et al. (2005). Oxygen isotope evidence for slab melting in modern and ancient subduction zones. Earth and Planetary Science Letters, 235, 480-496.

Bodinier, J. L., \& Godard, M. (2014). Orogenic, ophiolitic and abyssal peridotites. In R. W. Carlson (Ed.), Treatise on Geochemistry (second ed., pp. 103-167). Oxford: Elsevier.

Bodinier, J. L., Guiraud, M., Fabries, J., Dostal, J., \& Dupuy, C. (1987). Petrogenesis of layered pyroxenites from the Lherz, Freychinede and Prades ultramafic bodies (Ariege, French Pyrenees). Geochimica et Cosmochimica Acta, 51(2), 279-290.

Carlson, R. W., \& Ionov, D. A. (2019). Compositional characteristics of the MORB mantle and bulk silicate Earth based on spinel peridotites from the Tariat region, Mongolia. Geochimica et Cosmochimica Acta, 257, 206-223.

Chazot, G., Lowry, D., Mattey, D., \& Menzies, M. (1997). Oxygen isotopic composition of hydrous and anhydrous mantle peridotites. Geochimica et Cosmochimica Acta, 61(1), 161-169.

Chen, C. F., Liu, Y. S., Foley, S. F., Ducea, M. N., He, D. T., Hu, Z. C., et al. (2016). Paleo-Asian oceanic slab under the North China craton revealed by carbonatites derived from subducted limestones. Geology, 44, 1039-1042.

Chetouani, K., Bodinier, J. L., Garrido, C. J., Marchesi, C., Amri, I., \& Targuisti, K. (2016). Spatial variability of pyroxenite layers in the Beni Bousera orogenic peridotite (Morocco) and implications for their origin. Comptes Rendus Geoscience, 348, 619-629.

Chu, Z. Y., Wu, F. Y., Walker, R. J., Rudnick, R. L., Pitcher, L., Puchtel, I., et al. (2009). Temporal evolution of the lithospheric mantle beneath the eastern North China Craton. Journal of Petrology, 50, 1875-1898.

Daines, M. J., \& Kohlstedt, D. L. (1994). The transition from porous to channelized flow due to melt/rock reaction during melt migration. Geophysical Research Letters, 21, 145-148.

Dasgupta, R., \& Hirschmann, M. M. (2006). Melting in the Earth's deep upper mantle caused by carbon dioxide. Nature, 440(7084), 659-662. https://doi.org/10.1038/nature04612

Deng, L., Liu, Y., Zong, K., Zhu, L., Xu, R., Hu, Z., \& Gao, S. (2017). Trace element and Sr isotope records of multi-episode carbonatite metasomatism on the eastern margin of the North China Craton. Geochemistry, Geophysics, Geosystems, 18, 220-237. https://doi.org/ $10.1002 / 2016 \mathrm{GC} 006618$

Doucet, L. S., Ionov, D. A., Golovin, A. V., \& Pokhilenko, N. P. (2012). Depth, degrees and tectonic settings of mantle melting during craton formation: inferences from major and trace element compositions of spinel harzburgite xenoliths from the Udachnaya kimberlite, central Siberia. Earth and Planetary Science Letters, 359-360, 206-218.

Downes, H. (2007). Origin and significance of spinel and garnet pyroxenites in the shallow lithospheric mantle: Ultramafic massifs in orogenic belts in Western Europe and NW Africa. Lithos, 99, 1-24.

Feng, Z. Q., Jia, C. Z., Xie, X. N., Zhang, S., Feng, Z. H., \& Cross, T. A. (2010). Tectonostratigraphic units and stratigraphic sequences of the nonmarine Songliao basin, northeast China. Basin Research, 22, 79-95.

Foley, S. F. (2008). Rejuvenation and erosion of the cratonic lithosphere. Nature Geoscience, 1, 503-510.

Foley, S. F., Yaxley, G. M., Rosenthal, A., Buhre, S., Kiseeva, E. S., Rapp, R. P., \& Jacob, D. E. (2009). The composition of near-solidus melts of peridotite in the presence of $\mathrm{CO}_{2}$ and $\mathrm{H}_{2} \mathrm{O}$ between 40 and 60 kbar. Lithos, 112, 274-283.

Gao, S., Rudnick, R. L., Carlson, R. W., McDonough, W. F., \& Liu, Y. S. (2002). Re-Os evidence for replacement of ancient mantle lithosphere beneath the North China Craton. Earth and Planetary Science Letters, 198, 307-322.

Garrido, C. J., \& Bodinier, J. L. (1999). Diversity of mafic rocks in the Ronda peridotite: Evidence for pervasive melt-rock reaction during heating of subcontinental lithosphere by upwelling asthenosphere. Journal of Petrology, 40, 729-754. 
Green, D. H., \& Wallace, M. E. (1988). Mantle metasomatism by ephemeral carbonatite melts. Nature, 336, 459-462.

Guo, P., Xu, W. L., Wang, C. G., Wang, F., Ge, W. C., Sorokin, A. A., \& Wang, Z. W. (2017). Age and evolution of the lithospheric mantle beneath the Khanka Massif: Geochemical and isotope Re-Os evidence from Sviyagino mantle xenoliths. Lithos, 282-283, 326-338.

Guo, P., Xu, W. L., Wang, Z. W., Wang, F., \& Luan, J. P. (2018). Geochronology and geochemistry of late Devonian-Carboniferous igneous rocks in the Songnen-Zhangguangcai range massif, NE China: Constraints on the late Paleozoic tectonic evolution of the eastern central Asian Orogenic Belt. Gondwana Research, 57, 119-132.

Guo, Z., Chen, Y. J., Ning, J. Y., Yang, Y. J., \& Afonso, J. C. (2016). Seismic evidence of on-going sublithosphere upper mantle convection for intra-plate volcanism in Northeast China. Earth and Planetary Science Letters, 433, 31-43.

Hammouda, T. (2003). High-pressure melting of carbonated eclogite and experimental constraints on carbon recycling and storage in the mantle. Earth and Planetary Science Letters, 214(1-2), 357-368.

Herzberg, C. (2004). Geodynamic information in peridotite petrology. Journal of Petrology, 45, 2507-2530.

Herzberg, C. (2011). Identification of source lithology in the Hawaiian and Canary Islands: Implications for origins. Journal of Petrology, 52, $113-146$.

Hu, J., Jiang, N., Carlson, R. W., Guo, J., Fan, W., Huang, F., et al. (2019). Metasomatism of the crust-mantle boundary by melts derived from subducted sedimentary carbonates and silicates. Geochimica et Cosmochimica Acta, 260, 311-328.

Huang, J., \& Zhao, D. (2006). High-resolution mantle tomography of China and surrounding regions. Journal of Geophysical Research, 111, B09305. https://doi.org/10.1029/2005JB004066

Ionov, D. A. (2007). Compositional variations and heterogeneity in fertile lithospheric mantle: Peridotite xenoliths in basalts from Tariat, Mongolia. Contributions to Mineralogy and Petrology, 154, 455-477.

Ionov, D. A., Bigot, F., \& Braga, R. (2017). The provenance of the lithospheric mantle in continental collision zones: Petrology and geochemistry of peridotites in the Ulten-Nonsberg zone (eastern Alps). Journal of Petrology, 58(7), 1451-1472.

Ionov, D. A., Chanefo, I., \& Bodinier, J. L. (2005). Origin of Fe rich lherzolites and wehrlites from Tok, SE Siberia by reactive melt percolation in refractory mantle peridotites. Contributions to Mineralogy and Petrology, 150, 335-353.

Ionov, D. A., Gregoire, M., \& Prikhod'ko, V. S. (1999). Feldspar-Ti-oxide metasomatism in off-cratonic continental and oceanic upper mantle. Earth and Planetary Science Letters, 165, 37-44.

Ionov, D. A., Guo, P., Nelson, W. R., Shirey, S. B., \& Willbold, M. (2020). Paleoproterozoic melt-depleted lithospheric mantle in the Khanka block, far eastern Russia: Inferences for mobile belts bordering the North China and Siberian cratons. Geochimica et Cosmochimica Acta, 270, 95-111.

Ionov, D. A., Hofmann, A. W., \& Shimizu, N. (1994). Metasomatism-induced melting in mantle xenoliths from Mongolia. Journal of Petrology, 35, 753-785.

Ionov, D. A., Prikhod'Ko, V. S., \& O'Reilly, S. Y. (1995). Peridotite xenoliths in alkali basalts from the Sikhote-Alin, southeastern Siberia, Russia: Trace-element signatures of mantle beneath a convergent continental margin. Chemical Geology, 120, $275-294$.

Irving, A. J. (1980). Petrology and geochemistry of composite ultramafic xenoliths in alkali basalts and implications for magmatic processes within the mantle. American Journal of Science, 280-A, 389-426.

Kelemen, P. B., Hart, S. R., \& Bernstein, S. (1998). Silica enrichment in the continental upper mantle via melt/rock reaction. Earth and Planetary Science Letters, 164, 387-406.

Klemme, S., Van der Laan, S., Foley, S., \& Günther, D. (1995). Experimentally determined trace and minor element partitioning between clinopyroxene and carbonatite melt under upper mantle conditions. Earth and Planetary Science Letters, 133, 439-448.

Kornprobst, J., Piboule, M., Roden, M., \& Tabit, A. (1990). Corundum-bearing garnet clinopyroxenites at Beni Bousera (Morocco): Original plagioclase-rich gabbros recrystallized at depth within the mantle? Journal of Petrology, 31, 717-745.

Lambart, S., Laporte, D., Provost, A., \& Schiano, P. (2012). Fate of pyroxenite-derived melts in the peridotitic mantle: Thermodynamical and experimental constraints. Journal of Petrology, 53(3), 451-476.

Lambart, S., Laporte, D., \& Schiano, P. (2013). Markers of the pyroxenite contribution in the major element compositions of oceanic basalts: Review of the experimental constraints. Lithos, 160, 14-36.

Lee, C. T. A., Cheng, X., \& Horodyskyj, U. (2006). The development and refinement of continental arcs by primary basaltic magmatism, garnet pyroxenite accumulation, basaltic recharge and delamination: Insights from the Sierra Nevada, California. Contributions to Mineralogy and Petrology, 151(2), 222-242.

Li, S. G., Yang, W., Ke, S., Meng, X. N., Tian, H. C., Xu, L. J., et al. (2017). Deep carbon cycles constrained by a large-scale mantle Mg isotope anomaly in eastern China. National Science Review, 4, 111-120.

Liu, Y. J., Li, W. M., Feng, Z. Q., Wen, Q. B., Neubauer, F., \& Liang, C. Y. (2017). A review of the Paleozoic tectonics in the eastern part of central Asian Orogenic Belt. Gondwana Research, 43, 123-148.

Liu, Y. S., Gao, S., Lee, C. T., Hu, S. H., Liu, X. M., \& Yuan, H. L. (2005). Melt-peridotite interactions: Links between garnet pyroxenite and high-Mg\# signature of continental crust. Earth and Planetary Science Letters, 234, 39-57.

Luan, J. P., Xu, W. L., Wang, F., Wang, Z. W., \& Guo, P. (2017). Age and geochemistry of the Neoproterozoic granitoids in the the Songnen-Zhangguangcai Range Massif, NE China: Petrogenesis and tectonic implications. Journal of Asian Earth Sciences, 148, 265-276.

Mattey, D., Lowry, D., \& Macpherson, C. (1994). Oxygen isotope composition of mantle peridotite. Earth and Planetary Science Letters, 128(3-4), 231-241.

McDonough, M. F., \& Sun, S. S. (1995). The composition of the earth. Chemical Geology, 120(3), 223-253.

Menzies, M. A., Fan, W. M., \& Zhang, M. (1993). Palaeozoic and Cenozoic lithoprobes and the loss of $>120$ km of Archaean lithosphere, Sino-Korean craton, China. In H. M. Prichard, T. Alabaster, N. B. W. Harris, \& V. R. Neary (Eds.), Magmatic Processes and Plate Tectonics (Vol. 76, pp. 71-78). London: Geological Society, Lonon, Special Publications.

Miller, J. A., Cartwright, I., Buick, I. S., \& Barnicoat, A. C. (2001). An O-isotope profile through the HP-LT Corsican ophiolite, France and its implications for fluid flow during subduction. Chemical Geology, 178(1-4), 43-69.

Montanini, A., \& Tribuzio, R. (2015). Evolution of recycled crust within the mantle: Constraints from the garnet pyroxenites of the external Ligurian ophiolites (northern Apennines, Italy). Geology, 43, 911-914.

Montanini, A., Tribuzio, R., \& Thirlwall, M. (2012). Garnet clinopyroxenite layers from the mantle sequences of the northern Apennine ophiolites (Italy): Evidence for recycling of crustal material. Earth and Planetary Science Letters, 351-352, 171-181.

Morgan, Z. T., \& Liang, Y. (2003). An experimental and numerical study of the kinetics of harzburgite reactive dissolution with applications to dunite dike formation. Earth and Planetary Science Letters, 214, 59-74.

Morgan, Z. T., Liang, Y., \& Kelemen, P. B. (2008). Significance of the composition profiles associated with dunite bodies in the Josephine and Trinity ophiolites. Geochemistry, Geophysics, Geosystems, 9, Q07025. https://doi.org/10.1029/2008GC001954 
Muehlenbachs, K. (1986). Highly siderophile and strongly chalcophile elements in high temperature geochemistry and cosmochemistry. Reviews in Mineralogy \& Geochemistry Mineralogical Society of America, 16, 425-444.

Pearson, D. G., Canil, D., \& Shirey, S. B. (2014). Mantle samples included in volcanic rocks: xenoliths and diamonds. In R. W. Carlson (Ed.), Treatise on Geochemistry (second ed., pp. 169-253). Oxford: Elsevier.

Pei, F. P., Xu, W. L., Yang, D. B., Zhao, Q. G., Liu, X. M., \& Hu, Z. C. (2007). Zircon U-Pb geochronology of basement metamorphic rocks in the Songliao Basin. Chinese Science Bulletin, 52(7), 942-948.

Rudnick, R. L., Mcdonough, W. F., \& Chappell, B. W. (1993). Carbonatite metasomatism in the northern Tanzanian mantle: Petrographic and geochemical characteristics. Earth and Planetary Science Letters, 114(4), 463-475.

Sengör, A. M. C., Natal'in, B. A., \& Burtman, V. S. (1993). Evolution of the Altaid tectonic collage and Paleozoic crustal growth in Eurasia. Nature, 364, 299-307.

Sneeringer, M., Hart, S. R., \& Shimizu, N. (1984). Strontium and samarium diffusion in diopside. Geochimica et Cosmochimica Acta, 48(8), $1589-1608$.

Sobolev, A. V., Hofmann, A. W., Sobolev, S. V., \& Nikogosian, I. K. (2005). An olivine-free mantle source of Hawaiian shield basalts. Nature, 434(7033), 590-597. https://doi.org/10.1038/nature03411

Staudigel, H., Davies, G. R., Hart, S. R., Marchant, K. M., \& Smith, B. M. (1995). Large scale isotopic Sr, Nd and O isotopic anatomy of altered oceanic crust: DSDP/ODP sites417/418. Earth and Planetary Science Letters, 130(1-4), 169-185.

Suhr, G., Hellebrand, E., Snow, J. E., Seck, H. A., \& Hofmann, A. W. (2003). Significance of large, refractory dunite bodies in the upper mantle of the Bay of Islands ophiolite. Geochemistry, Geophysics, Geosystems, 4(3), 8605. https://doi.org/10.1029/2001GC000277

Takazawa, E., Frey, F. A., Shimizu, N., \& Obata, M. (2000). Whole rock compositional variations in an upper mantle peridotite (Horoman, Hokkaido, Japan): Are they consistent with a partial melting process. Geochimica et Cosmochimica Acta, 64(4), 695-716.

Tang, J., Xu, W. L., Wang, F., Zhao, S., \& Wang, W. (2016). Early Mesozoic southward subduction history of the Mongol-Okhotsk oceanic plate: Evidence from geochronology and geochemistry of Early Mesozoic intrusive rocks in the Erguna Massif, NE China. Gondwana Research, 31, 218-240.

Tang, Y., Obayashi, M., Niu, F., Grand, S. P., Chen, Y. J., Kawakatsu, H., et al. (2014). Changbaishan volcanism in Northeast China linked to subduction-induced mantle upwelling. Nature Geoscience, 7(6), 470-475.

Tian, H. C., Yang, W., Li, S. G., Ke, S., \& Chu, Z. Y. (2016). Origin of low $\delta^{26} \mathrm{Mg}$ basalts with EM-I component: Evidence for interaction between enriched lithosphere and carbonated asthenosphere. Geochimica et Cosmochimica Acta, 188, 93-105.

Tursack, E., \& Liang, Y. (2012). A comparative study of melt-rock reactions in the mantle: Laboratory dissolution experiments and geological field observations. Contributions to Mineralogy and Petrology, 163, 861-876.

Varas-Reus, M. I., Garrido, C., Marchesi, C., Bodinier, J. L., Frets, E., Bosch, D., et al. (2016). Refertilization processes in the subcontinental lithospheric mantle: The record of the Beni Bousera orogenic peridotite (Rif Belt, northern Morocco). Journal of Petrology, 57(11-12), $2251-2270$.

Walker, R. J., Carlson, R. W., Shirey, S. B., \& Boyd, F. R. (1989). Os, Sr, Nd, and Pb isotope systematics of southern African peridotite xenoliths: Implications for the chemical evolution of subcontinental mantle. Geochimica et Cosmochimica Acta, 53(7), $1583-1595$.

Wallace, M. E., \& Green, D. H. (1988). An experimental determination of primary carbonatite magma composition. Nature, 335(6188), 343.

Wang, C., Liang, Y., Dygert, N., \& Xu, W. L. (2016). Formation of orthopyroxenite by reaction between peridotite and hydrous basaltic melt: An experimental study. Contributions to Mineralogy and Petrology, 171, 1-18.

Wang, C. G., Xu, W. L., Yang, D. B., Liu, Y. S., Pei, F. P., Li, Q. L., \& Zhou, Q. J. (2018). Olivine oxygen isotope evidence for Intracontinental recycling of delaminated continental crust. Geochemistry, Geophysics, Geosystems, 19, 1913-1924. https://doi.org/10.1029/ 2017GC007284

Wang, L. C. (1996). The occurrence of Dashihe olivine deposit in Jilin Province. Chinese Journal of Changchun University of Earth and Science, 26, 43-46. (in Chinese with English abstract)

Wang, X. J., Chen, L. H., Hofmann, A. W., Mao, F. G., Liu, J. Q., Zhong, Y., et al. (2017). Mantle transition zone-derived EM1 component beneath NE China: Geochemical evidence from Cenozoic potassic basalts. Earth and Planetary Science Letters, 465, 16-28.

Wang, Y., Zhang, F. Q., Zhang, D. W., Miao, L. C., Li, T. S., Xie, H. Q., et al. (2006). Zircon SHRIMP U-Pb dating of meta-diorite from the basement of the Songliao Basin and its geological significance. Chinese Science Bulletin, 51, 1877-1883.

Wang, Z. W., Xu, W. L., Pei, F. P., Wang, F., Guo, P., Wang, F., \& Li, Y. (2017). Geochronology and geochemistry of early Paleozoic igneous rocks from the Zhangguangcai Range, northeastern China: Constraints on tectonic evolution of the eastern central Asian Orogenic Belt. Lithosphere, 9(5), 803-827.

Wei, W., Zhao, D., Xu, J., Wei, F., \& Liu, G. (2015). P and S wave tomography and anisotropy in Northwest Pacific and East Asia: Constraints on stagnant slab and intraplate volcanism. Journal of Geophysical Research: Solid Earth, 120, 1642-1666. https://doi.org/ 10.1002/2014JB011254

Workman, R. K., \& Hart, S. R. (2005). Major and trace element composition of the depleted MORB mantle (DMM). Earth and Planetary Science Letters, 231(1-2), 53-72.

Wu, F. Y., Sun, D. Y., Ge, W. C., Zhang, Y. B., Grant, M. L., Wilde, S. A., \& Jahn, B. M. (2011). Geochronology of the Phanerozoic granitoids in northeastern China. Journal of Asian Earth Sciences, 41, 1-30.

Wu, F. Y., Walker, R. J., Ren, X., Sun, D., \& Zhou, X. (2003). Osmium isotopic constraints on the age of lithospheric mantle beneath northeastern China. Chemical Geology, 196(1-4), 107-129.

Wu, F. Y., Walker, R. J., Yang, Y. H., Yuan, H. L., \& Yang, J. H. (2006). The chemical-temporal evolution of lithospheric mantle underlying the North China Craton. Geochimica et Cosmochimica Acta, 70, 5013-5034.

Xi, Q. K., Liu, J., Kovács, I., Hao, Y. T., Li, P., Yang, X. Z., et al. (2019). Water in the upper mantle and deep crust of eastern China: Concentration, distribution and implications. National Science Review, 6, 125-144.

Xiao, W. J., Windley, B. F., Sun, S., Li, J. L., Huang, B. C., Han, C. M., et al. (2015). A tale of amalgamation of three Permo-Triassic collage systems in Central Asia: Oroclines, sutures, and terminal accretion. Annual Review of Earth and Planetary Sciences, 43, $477-507$.

Xu, R., Liu, Y. S., Tong, X. R., Hu, Z. C., Zong, K. Q., \& Gao, S. (2013). In-situ trace elements and Li and Sr isotopes in peridotite xenoliths from Kuandian, North China Craton: Insights into Pacific slab subduction-related mantle modification. Chemical Geology, 354, 107-123.

Xu, W. L., Pei, F. P., Wang, F., Meng, E., Ji, W. Q., Yang, D. B., \& Wang, W. (2013). Spatial-temporal relationships of Mesozoic volcanic rocks in NE China: Constraints on tectonic overprinting and transformations between multiple tectonic regimes. Journal of Asian Earth Sciences, 74, 167-193. 
Xu, Y., Mercier, J. C. C., Menzies, M. A., Ross, J. V., Harte, B., Lin, C., \& Shi, L. (1996). K-rich glass-bearing wehrlite xenoliths from Yitong, Northeastern China: Petrological and chemical evidence for mantle metasomatism. Contributions to Mineralogy and Petrology, 125(4), 406-420.

Xu, Y. G. (2001). Thermo-tectonic destruction of the Archaean lithospheric keel beneath the Sino-Korean craton in China: Evidence, timing and mechanism. Physics and Chemistry of the Earth, 26, 747-757.

$\mathrm{Xu}$, Y. G. (2014). Recycled oceanic crust in the source of 90-40 Ma basalts in North and Northeast China: Evidence, provenance and significance. Geochimica et Cosmochimica Acta, 143, 49-67.

Xu, Y. G., Menzies, M. A., Thirlwall, M. F., Huang, X. L., Liu, Y., \& Chen, X. M. (2003). "Reactive” harzburgites from Huinan, NE China: Products of the lithosphere-asthenosphere interaction during lithospheric thinning? Geochimica et Cosmochimica Acta, 67, 487-505.

Xu, Y. G., Menzies, M. A., Vroon, P., Mercier, J. C., \& Lin, C. Y. (1998). Texture-temperature-geochemistry relationships in the upper mantle as revealed from Spinel Peridotite xenoliths from Wangqing, NE China. Journal of Petrology, 39, 469-493.

Xu, Y. G., Zhang, H. H., Qiu, H. N., Ge, W. C., \& Wu, F. Y. (2012). Oceanic crust components in continental basalts from Shuangliao, Northeast China: Derived from the mantle transition zone? Chemical Geology, 328, 168-184.

Yaxley, G., \& Green, D. (1998). Reactions between eclogite and peridotite: Mantle refertilisation by subduction of oceanic crust. Schweizerische Mineralogische und Petrographische Mitteilungen, 78, 243-255.

Yaxley, G. M., Crawford, A. J., \& Green, D. H. (1991). Evidence for carbonatite metasomatism in spinel peridotite xenoliths from western Victoria, Australia. Earth and Planetary Science Letters, 107, 305-317.

Yu, S. Y., Xu, Y. G., Huang, X. L., Ma, J. L., Ge, W. C., Zhang, H. H., \& Qin, X. F. (2009). Hf-Nd isotopic decoupling in continental mantle lithosphere beneath Northeast China: Effects of pervasive mantle metasomatism. Journal of Asian Earth Sciences, 35, 554-570.

Yu, S. Y., Xu, Y. G., Ma, J. L., Zheng, Y. F., Kuang, Y., Hong, L. B., et al. (2010). Remnants of oceanic lower crust in the subcontinental lithospheric mantle: Trace element and $\mathrm{O}$ isotope evidence from aluminous garnet pyroxenite xenoliths from Jiaohe, Northeast China. Earth and Planetary Science Letters, 297, 413-422.

Zhang, G. L., Chen, L. H., Jackson, M. G., \& Hofmann, A. W. (2017). Evolution of carbonated melt to alkali basalt in the South China Sea. Nature Geoscience, 10(3), 229-235.

Zhang, Y. L., Ge, W. C., Sun, J., Yang, H., Liu, C. Z., Liu, Z. C., \& Liu, J. G. (2019). Age and composition of the subcontinental lithospheric mantle beneath the Xing'an-Mongolia Orogenic Belt: Implications for the construction of microcontinents during accretionary orogenesis. Lithos, 326-327, 556-571.

Zhang, Y. L., Liu, C. Z., Ge, W. C., Wu, F. Y., \& Chu, Z. L. (2011). Ancient sub-continental lithospheric mantle (SCLM) beneath the eastern part of the Central Asian Orogenic Belt (CAOB): Implications for crust-mantle decoupling. Lithos, 126, 233-247.

Zheng, J. P., Griffin, G. L., O’Reilly, S. Y., Yang, J. S., Li, T. F., Zhang, M., et al. (2006). Mineral chemistry of peridotites from Paleozoic, Mesozoic and Cenozoic lithosphere: Constraints on mantle evolution beneath eastern China. Journal of Petrology, 47, $2233-2256$.

Zhou, Q., Wu, F. Y., Chu, Z. Y., Yang, Y. H., Sun, D. Y., \& Ge, W. C. (2007). Sr-Nd-Hf-Os isotopic characterizations of the Jiaohe peridotite xenoliths in Jilin province and constraints on the lithospheric mantle age in northeastern China. Acta Petrologica Sinica, 23, 1269-1280.

Zhu, R. X., Xu, Y. G., Zhu, G., Zhang, H. F., \& Zheng, T. Y. (2012). Destruction of the North China Craton. Science China (D), 55, 1565-1587. 